Article

\title{
The Dynamics, Ecological Variability and Estimated Carbon Stocks of Mangroves in Mahajamba Bay, Madagascar
}

Trevor G. Jones ${ }^{1,2, *}$, Harifidy Rakoto Ratsimba ${ }^{3}$, Lalao Ravaoarinorotsihoarana ${ }^{\mathbf{1}}$, Leah Glass ${ }^{\mathbf{1}}$, Lisa Benson ${ }^{1}$, Marianne Teoh ${ }^{4}$, Aude Carro ${ }^{1}$, Garth Cripps ${ }^{1}$, Chandra Giri ${ }^{5}$, Samir Gandhi ${ }^{1}$, Zo Andriamahenina ${ }^{1}$, Rado Rakotomanana ${ }^{1}$ and Pierre-Francois Roy ${ }^{6}$

1 Blue Ventures Conservation, Villa Bella Fiharena, Rue Gambetta, Lot 259, Toliara 601, Madagascar; E-Mails: lalao@blueventures.org (L.R.); leah@blueventures.org (L.G.); lisa.benson@blueventures.org (L.B.); aude@blueventures.org (A.C.); garth@blueventures.org (G.C.); samir@blueventures.org (S.G.); zo@blueventures.org (Z.A.); rado@blueventures.org (R.R.) Dynamic Ecosystems and Landscapes Lab, Department of Environmental Science and Management, Portland State University, Portland, OR 97207, USA

3 Department of Forestry, University of Antananarivo, PO Box 175, Antananarivo 101, Madagascar; E-Mail: rrharifidy@yahoo.fr

4 The Song Saa Foundation 108 e1, Street 19, Phnom Penh 12206, Cambodia; E-Mail: marianne@songsaa.com

5 United States Geological Survey, Earth Resources Observation and Science Center, Duke University, Durham, NC 27708, USA; E-Mail: cgiri@usgs.gov

6 Catholic Institute of Arts and Crafts, 75 Avenue de Grande Bretagne, Toulouse 313000, France; E-Mail: pierrefrancois.roy@gmail.com

* Author to whom correspondence should be addressed; E-Mail: trevor@blueventures.org. Academic Editor: Joseph M. Smoak

Received: 30 May 2015 / Accepted: 29 July 2015 / Published: 4 August 2015

\begin{abstract}
Mangroves are found throughout the tropics, providing critical ecosystem goods and services to coastal communities and supporting rich biodiversity. Globally, mangroves are being rapidly degraded and deforested at rates exceeding loss in many tropical inland forests. Madagascar contains around $2 \%$ of the global distribution, $>20 \%$ of which has been deforested since 1990, primarily from over-harvest for forest products and conversion for agriculture and aquaculture. While historically not prominent, mangrove loss in
\end{abstract}


Madagascar's Mahajamba Bay is increasing. Here, we focus on Mahajamba Bay, presenting long-term dynamics calculated using United States Geological Survey (USGS) national-level mangrove maps contextualized with socio-economic research and ground observations, and the results of contemporary (circa 2011) mapping of dominant mangrove types. The analysis of the USGS data indicated 1050 hectares (3.8\%) lost from 2000 to 2010 , which socio-economic research suggests is increasingly driven by commercial timber extraction. Contemporary mapping results permitted stratified sampling based on spectrally distinct and ecologically meaningful mangrove types, allowing for the first-ever vegetation carbon stock estimates for Mahajamba Bay. The overall mean carbon stock across all mangrove classes was estimated to be $100.97 \pm 10.49 \mathrm{Mg} \mathrm{C} \mathrm{ha}^{-1}$. High stature closed-canopy mangroves had the highest average carbon stock estimate (i.e., $166.82 \pm 15.28 \mathrm{Mg} \mathrm{C}^{-1}$ ). These estimates are comparable to other published values in Madagascar and elsewhere in the Western Indian Ocean and demonstrate the ecological variability of Mahajamba Bay's mangroves and their value towards climate change mitigation.

Keywords: Madagascar; mangrove; carbon; Landsat; dynamics; coastal; Payments for Ecosystem Services (PES)

\section{Introduction}

Mangrove ecosystems provide a diverse range of goods (e.g., food, medicine, construction materials, fuel) and services (e.g., storm and erosion protection, water filtration, faunal breeding, nesting, nursing, and feeding grounds) to coastal communities, support high levels of biodiversity, and sequester significant amounts of $\mathrm{CO}_{2}$ in intertidal areas in over 120 countries between $30^{\circ} \mathrm{N}$ and $\mathrm{S}$ latitude [1-20]. Regardless of their value, global mangrove loss has been rapid and widespread over the past several decades with annual estimates at $1 \%-2 \%$, exceeding deforestation and conversion rates in many inland tropical forests $[6,21-25]$. Substantial portions of the world's remaining mangroves are already degraded and if current trends progress unimpeded, many of these ecosystems may functionally collapse within this century [22,26,27]. While variable by country, principal anthropogenic drivers of loss involve conversion for small- to industrial-scale agriculture and aquaculture, over-harvest for forest products, coastal development, and the erosion, sedimentation, and siltation caused by upstream terrestrial agriculture and deforestation [28-37]. Natural processes and events including forest succession and sedimentological processes, tropical storms, and sea-level rise are also significant drivers of mangrove dynamics, and as the global climate continues to change, the frequency and magnitude of extreme weather events and the impact of the rising sea-level are expected to increase [6,11,25,28,34,37-42].

Contemporary information on the extent and status of mangroves is required to understand dynamics for effective management and decision-making and can be provided through mapping and monitoring using remotely sensed data $[15,43]$. While there is an ever-increasing diversity of remotely sensed data sources, the freely available Landsat satellite image archive extends back $>40$ years and is proven for identifying and inventorying mangrove extent and loss, and stratifying mangrove areas based on dominant ecological properties [44-56]. 
As of 2010, Madagascar contained approximately $2 \%$ of the global mangrove distribution, covering an estimated $2100 \mathrm{~km}^{2}$ primarily along its west coast, representing Africa's fourth-largest extent $[10,52,57,58]$. As throughout much of the world, in parts of the country, Madagascar's mangrove ecosystems are being rapidly degraded and, in some areas, converted for small- and industrial-scale agriculture and aquaculture or clear-cut for forest products (e.g., charcoal and timber). In northwestern Mahajamba Bay, mangrove modification and conversion are comparatively not yet widespread, but increased degradation and deforestation have been observed in recent years. For Madagascar, existing national-level maps derived from Landsat data allow for quantifying long-term mangrove dynamics, but lack the detail required to partition individual ecosystems based on ecologically distinct mangrove types associable with dissimilar carbon stock estimates. While several studies have used Landsat and spatially finer data for localized mapping of Mahajamba Bay's mangroves (e.g., [59-61]), the resulting information is out of date and also lacks the detail required to stratify based on ecological properties associable with distinct carbon stocks.

Here, we analyze existing national-level mangrove data to calculate dynamics for Mahajamba Bay. Socioeconomic research is used to contextualize the anthropogenic and natural drivers of loss. Employing Landsat data, we produce a contemporary (circa 2011) map of multiple ecologically distinct mangrove types and surrounding terrestrial land-cover types. Using this map to delineate mangrove strata and establish a network of field plots, we provide the first-ever above- and below-ground carbon vegetation stock estimates for Mahajamba Bay's mangroves and compare them with other published values in Madagascar (i.e., Ambaro-Ambanja Bays), elsewhere in the Western Indian Ocean (WIO) (i.e., Mozambique), and throughout the tropics (i.e., Mexico and Micronesia).

\section{Experimental Section}

\subsection{Study Area}

The area of interest (AOI) encompasses the marine and terrestrial extent below 30 meters (m) elevation within a seven kilometer $(\mathrm{km})$ coastal buffer of Mahajamba Bay (centered at latitude

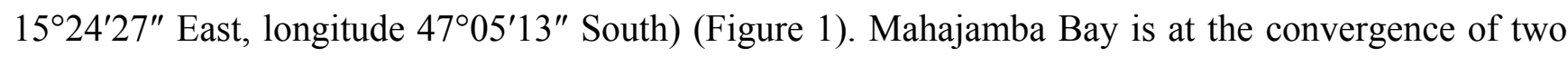
major coastal rivers, the Sofia and the Mahajamba, and according to Giri [58], contains Madagascar's largest mangrove ecosystem, totaling $>26,000$ hectares (ha). The Bay is a tidal plain, inundated twice daily by sea water with a tidal amplitude of 1.5-3 m (4-4.5 m during spring tide) and average surface water salinity from 25 to 45 per thousand [59,60]. Mean annual precipitation is approximately 1500 millimeters (mm), falling mostly from November to April [60]. The comparative abundance of rainfall and exposure to fresh river water contributes to the higher stature of the mangrove trees than those further south [57,62].

Except the approximately 800 ha of mangroves within the area leased by Aquaculture de la Mahajamba (AQUALMA), mangroves in the AOI are state-owned and regionally managed. Throughout their distribution, commercial exploitation is officially forbidden. Local communities are, however, permitted to extract forest products for self-consumption as part of their traditional user rights. As of 2001, the population of the six municipalities (i.e., communes) surrounding Mahajamba Bay was estimated at 57,700 [63]. Based on an inventory of settlements carried out in March 2015, using both 
local knowledge and Google Earth imagery, approximately 19,000 people spread across 170 villages and hamlets are permanent or temporary residents of the Bay's shores. As of 2001, farming was the primary economic activity for more than two-thirds of the population (69\%), followed by fisheries (27\%). Manufacturing and other activities employed the remaining 4\%. The area is characterized by high poverty rates, with nearly half the population considered either "poor" (40\%) or "extremely poor" (5\%) [63]. Primary development constraints include the lack of a reliable road network, and access to healthcare and education services. Fishing communities living in remote settlements also have scarce access to potable water and markets. In the AOI as throughout much of coastal Madagascar, the livelihoods of coastal communities are reliant on healthy, intact mangrove ecosystems. With minimal governance, a rising population, and other external and internal factors contributing to increasing economic pressures, anthropogenic activities and, thus, pressure on mangrove and related fisheries resources continue to grow in their range, frequency, and magnitude.

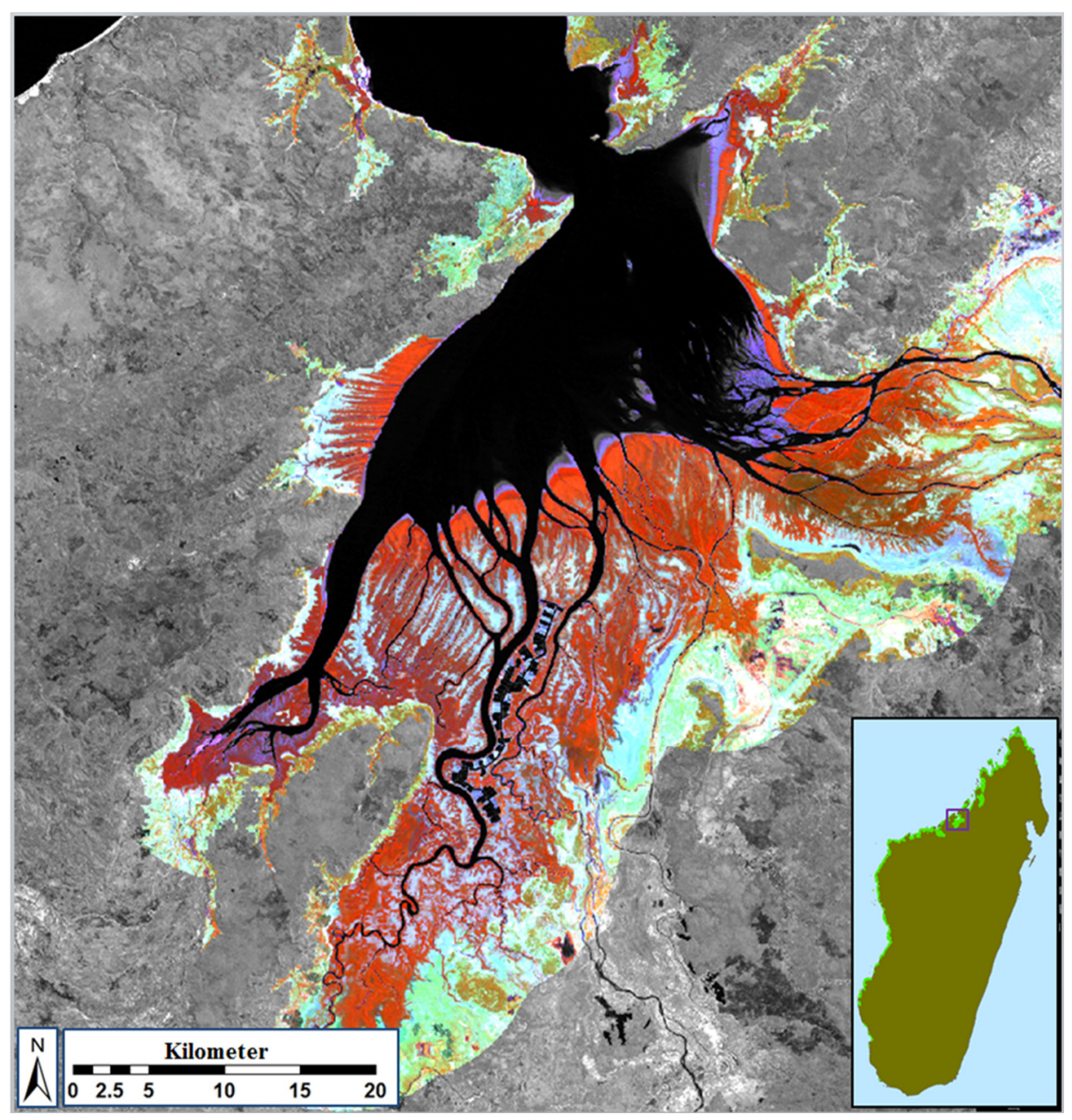

Figure 1. The AOI extent is shown using a masked false color composite of Landsat 5 Thematic Mapper (TM) bands 3, 5, and 4, wherein mangrove vegetation appears primarily in vibrant shades of red and orange. The background image is Landsat 5 TM band 4. The location within Madagascar and the national distribution of mangroves (bright green) are shown in the country-wide inset (bottom right: data obtained from Giri [58]). 


\subsection{Review of Existing Maps and Calculation and Contextualization of Mangrove Dynamics}

Several studies employed remotely sensed data to characterize Mahajamba Bay's mangroves [59-61]: Rasolofoharinoro et al. [59] used Satellite Pour l'Observation de la Terre (SPOT) data to delineate seven intertidal vegetation zones, including four mangrove classes (i.e., pioneering, dense mature, decaying, back) circa 1986 and 1993; Pasqualini et al. [60] employed a combination of SPOT and radar data to map 10 coastal ecosystem types for 1993, including four mangrove types as defined by their morphological (i.e., frontal, interfluvial) and dynamic (i.e., mature, recessive) properties; Guillet et al. [61] combined Landsat and SPOT data to define 12 classes for 1973, 1989, 2000, and 2006, including four mangrove types (i.e., sparse Avicennia marina, average density Avicennia marina, dense Avicennia marina, and dense Rhizophora mucronata). For all of these studies, the information is no longer contemporary and is also unable to guide stratification based on ecological properties associable with distinct carbon stocks.

Several studies have also resulted in national-level mangrove distribution for Madagascar [57,64-66]. Mayaux et al. [64] mapped six vegetation cover types, including mangroves, for 1998/1999 using a $1 \mathrm{~km}$ SPOT VEGETATION data-set. The Critical Ecosystem Partnership Fund (CEPF) [65] Madagascar Mapping Project produced a 15-category vegetation type map circa 2001, including a mangrove class, employing Moderate-resolution Imaging Spectroradiometer (MODIS) and Landsat data. Harper et al. [66] produced forest cover maps using Landsat for 1973, 1990, and 2000, which included a mangrove category. Employing methods described in Giri and Muhlhausen [57], Landsat data were used by Chandra, Giri and associates to delineate two categories (mangrove and non-mangrove) for 1973, 1990, 2000, 2005, and 2010 [58]. National-level data-sets were compared with references to contemporary Landsat data, finer spatial resolution imagery, and preliminary field observations to establish which offered the most representative information. Given that Google Earth imagery was not available after 2005 for most of the AOI, eight WorldView-2-2 (DigitalGlobe, Longmont, CO, USA) and Quickbird scenes offering partial coverage from 2010 to 2012 were acquired for detailed reference through Spatial Solutions, Inc. (Bend, OR, USA). The most representative maps were used to calculate mangrove dynamics (i.e., loss, gain, and persistence).

To contextualize dynamics, socio-economic research was undertaken within all six communes surrounding Mahajamba Bay during field visits in June and August 2012. Research was undertaken through focus group discussions, participatory mapping sessions, and interviews with a diverse cross-section of members of mangrove-adjacent communities. The methods used adhered to guidelines from the Social and Biodiversity Impact Assessment (SBIA) Manual for Reducing Emissions from Deforestation and Degradation plus sustainable management of forests, conservation of forest carbon stocks and enhancement of forest carbon stocks (REDD+) Projects [67,68].

\subsection{Remotely Sensed Data: Acquisition and Pre-Processing}

A $30 \mathrm{~m}$ spatial resolution Landsat 5 Thematic Mapper (TM) scene (path/row: 160/71) was downloaded from the United States Geological Survey (USGS) Earth Resources Observation and Science Center (Sioux Falls, SD, USA) offering comprehensive coverage of the AOI on 29 July 2011, during a low-tide of $1.7 \mathrm{~m}$. The Landsat scene was acquired and orthorectified to a Shuttle Radar Topography Mission (SRTM) digital elevation model (DEM). Following acquisition, the Cos(t) 
model [69] was employed to estimate the effects of absorption by atmospheric gases and Rayleigh scattering, remove systematic atmospheric haze, and convert image units to at-surface reflectance.

The bounding extent of the AOI was defined based on distance to coastline as a mangrove habitat requirement $[50,53,70]$ (Figure 1). Reducing the portions of the AOI to be classified can raise classification accuracy by lowering spectral confusion among mapped classes [52]. Based on numerous studies that demonstrate the utility of SRTM data for estimating mangrove forest canopy heights (e.g., [71-75]), an SRTM height mask further eliminated scene components through a $30 \mathrm{~m}$ elevation threshold, above which mangrove habitats and surrounding ecosystems were observed not to be found. The $30 \mathrm{~m}$ threshold was arrived at based on existing mangrove distribution maps, finer spatial resolution imagery, preliminary field-recorded height measurements, and a similar approach taken for Madagascar's mangroves by Jones et al. [56].

Table 1. Mapped classes and descriptions, per-class calibration, and validation reference areas.

\begin{tabular}{|c|c|c|c|}
\hline Class & Description of Typical Constituents & Calibration & Validation \\
\hline Active cultivation & dominated by active agriculture (e.g., rice) & 14 & 7 \\
\hline $\begin{array}{l}\text { Closed-canopy } \\
\text { terrestrial forest }\end{array}$ & closed-canopy terrestrial forest; canopy $>60 \%$ closed & 14 & 7 \\
\hline $\begin{array}{l}\text { Open-canopy } \\
\text { terrestrial forest }\end{array}$ & $\begin{array}{l}\text { open-canopy terrestrial forest; canopy } 30 \%-70 \% \text { closed; mosaics of trees, shrubs, } \\
\text { grass }\end{array}$ & 16 & 8 \\
\hline $\begin{array}{l}\text { Closed-canopy } \\
\text { mangrove I }\end{array}$ & tall, mature stands of trees; canopy $>80 \%$ closed & 22 & 10 \\
\hline $\begin{array}{l}\text { Closed-canopy } \\
\text { mangrove II }\end{array}$ & tall mature stands of trees; canopy $>60 \%$ closed & 22 & 10 \\
\hline $\begin{array}{l}\text { Open-canopy } \\
\text { mangrove I }\end{array}$ & $\begin{array}{l}\text { short-medium stands of trees/shrubs; canopy } 30 \%-70 \% \text { closed; moderately } \\
\text { influenced by background soil/mud }\end{array}$ & 14 & 7 \\
\hline $\begin{array}{l}\text { Open-canopy } \\
\text { mangrove II }\end{array}$ & $\begin{array}{l}\text { short-medium stands of trees/shrubs; canopy } 30 \%-70 \% \text { closed; significantly } \\
\text { influenced by background soil/mud }\end{array}$ & 12 & 7 \\
\hline $\begin{array}{l}\text { Open-canopy } \\
\text { mangrove III }\end{array}$ & $\begin{array}{l}\text { stunted, short stands, shrub-dominant, very sparse; canopy }<30 \% \text { closed; } \\
\text { dominated by exposed soil/mud }\end{array}$ & 14 & 7 \\
\hline Exposed soil & $\begin{array}{l}\text { dry inactive agri/aquacultural areas; dry tannes (mudflats); sparsely vegetated soil- } \\
\qquad \text { dominated areas }\end{array}$ & 21 & 10 \\
\hline Exposed mud & $\begin{array}{l}\text { mangrove/ocean interface; river sediment; wet tannes (mud-flats); inactive } \\
\text { aquacultural ponds }\end{array}$ & 14 & 7 \\
\hline
\end{tabular}

\subsection{Definition and Refinement of Mangrove and Surrounding Land-Cover Types}

Unsupervised classification of remotely sensed data is a typical preliminary step used for mapping mangroves and closely related ecosystem types [52,54,56,57,73,74,76,77]. Using an unsupervised iterative self-organizing classification algorithm (i.e., ISOCLUST), the pixels in the Landsat TM image were grouped together into dominant cover types based on their shared spectral properties in bands 1-5 and 7. The resulting preliminary classification was also used to remove areas dominated by water and shadow. Dominant mangrove and other cover types were then labeled and aggregated iteratively, making reference to existing maps and WorldView-2-2 and Quickbird data. While there is tremendous variability in the term "mangrove", here we refer to salt-tolerant halophytic trees and shrubs found in tidal/intertidal 
zones [78]. Mangrove type definitions were based on broad categories typified by spectral differences attributed to tangible ecological properties such as canopy-cover, stature, and density (Table 1).

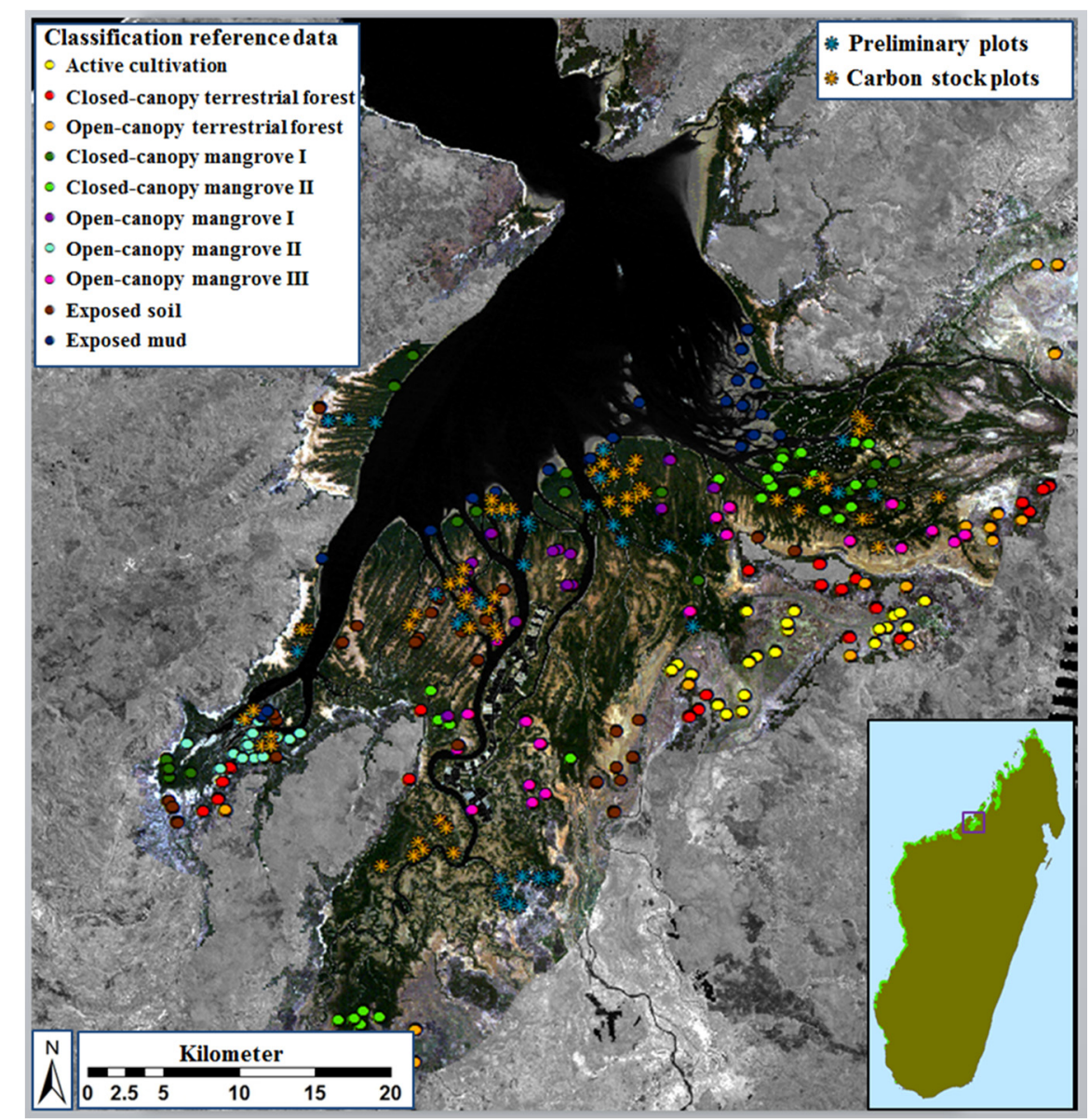

Figure 2. The locations of 43 preliminary mangrove plots and 243 reference areas used to calibrate (i.e., 163) and validate (i.e., 80) image classification. Also shown are the locations of 51 carbon plots. The AOI extent is shown using a masked true color composite of Landsat 5 Thematic Mapper (TM) bands 1, 2, and 3, wherein vegetation appears primarily in shades of green. The background image is Landsat 5 TM band 4 .

To assess the representativeness of and refine mangrove and surrounding land-cover categories, a preliminary field survey was conducted in June 2012. A stratified random sampling approach was employed, wherein potential plot locations were randomly targeted within dominant mangrove and other land-cover types based on preliminary classification results. In total, $43100 \times 100 \mathrm{~m}$ (i.e., ha-sized) nested preliminary plots were established within five dominant mangrove types (Table 1; Figure 2). Ha-sized plots were used to confidently locate areas representing spectrally distinct mangrove types within the Landsat image. Within each preliminary plot, tree height, species dominance, stature, age, density and canopy-cover, micro-relief, level of tidal-inundation, and the presence of natural and anthropogenic disturbance were recorded qualitatively. Within five systematically located $10 \times 10 \mathrm{~m}$ sub-plots, the diameter, height, and crown dimensions of trees were recorded using a Vertex hypsometer for representative examples of each mangrove species present. In addition, litter, understory, regeneration, stumps, and standing dead-wood were inventoried, and canopy-cover was quantified using 
a densiometer. Preliminary plots were used as classification reference data to facilitate both calibrating the spectral properties of different mangrove types for image classification (i.e., calibration) and assessing the accuracy of the resulting map (i.e., validation) (Table 1). Classification reference data were also defined based on plots established within seven non-mangrove classes (Table 1), wherein field notes and photographs recorded variability and confirmed representativeness. At all plot centers, a Garmin GPSmap 62sc GPS (Garmin International, Inc., Olathe, KS, USA) unit was left recording during the duration of measurements. Following the first field mission, additional classification reference areas were located in WorldView-2-2 (DigitalGlobe, Longmont, CO, USA) and Quickbird imagery (DigitalGlobe, Longmont, CO, USA) for all mapped categories, based on the familiarity gained with the appearance and location of target classes. In total, 243 classification reference areas, all of which were $3 \times 3$ Landsat pixels (i.e., $90 \times 90 \mathrm{~m}$ ) in dimension, were spread throughout the AOI and randomly partitioned to facilitate both calibration (i.e., 163) and validation (i.e., 80) (Figure 2). Examples of mapped classes as they appear in moderate spatial resolution Landsat data and fine spatial resolution WorldView-2 and Quickbird data are shown in Figure 3.

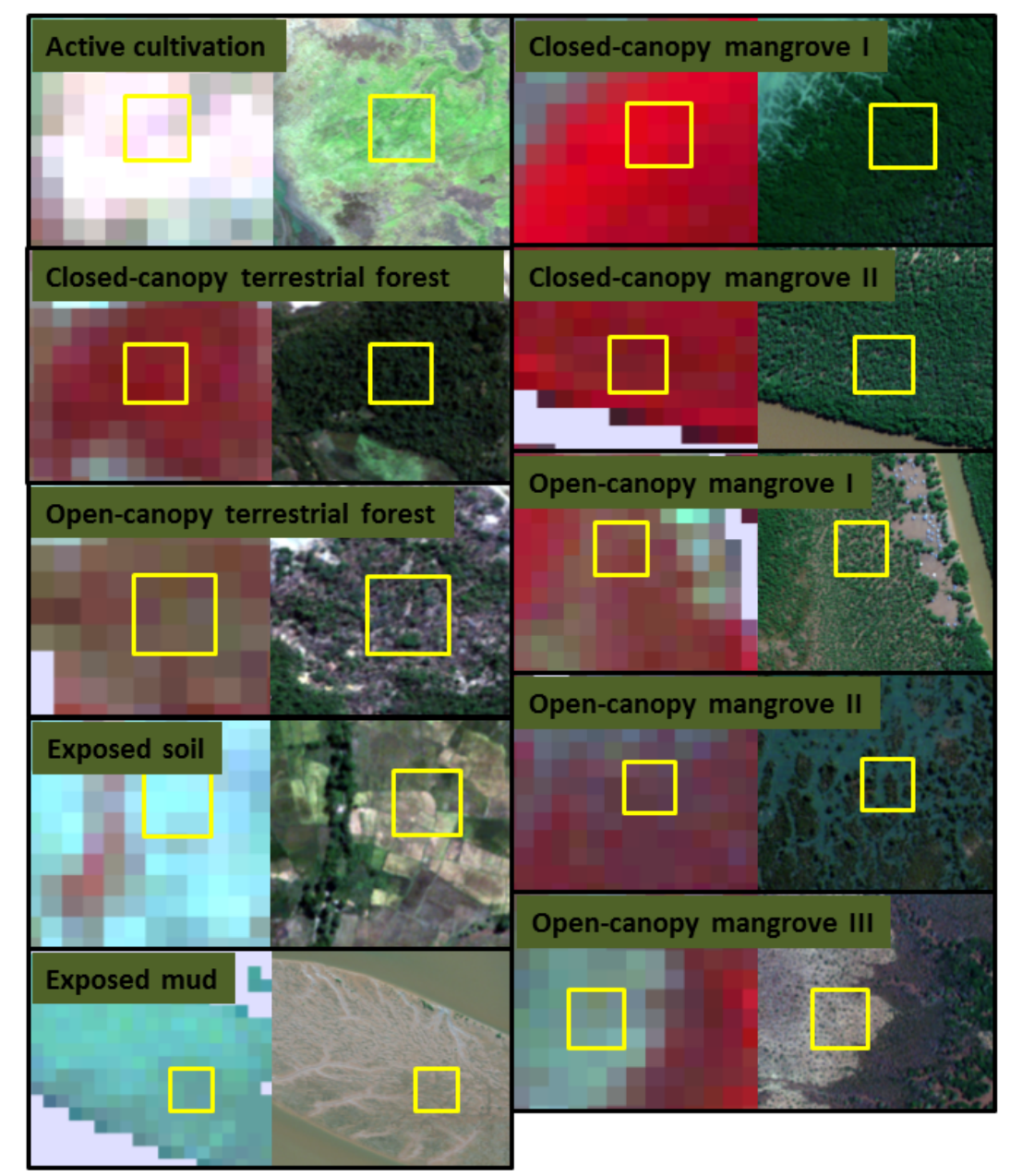

Figure 3. The appearance of mapped classes in moderate spatial resolution Landsat imagery (false color composites of bands 3,5, and 4, wherein terrestrial and mangrove vegetation appear in shades of red: left-side boxes) and finer spatial resolution WorldView-2-2 and Quickbird imagery (true color composites: right-side boxes). Yellow boxes represent $90 \times 90 \mathrm{~m}$ reference areas. 


\subsection{Image Classification and Map Production}

Using the statistical properties of the spectral values in Landsat TM spectral bands 1-5 and 7 of classification reference areas to define membership criteria, the maximum likelihood (ML) classification algorithm was employed to produce a map of class distributions. The robustness of the ML routine for classifying mangrove habitats with Landsat-like data has been repeatedly demonstrated [53,55,56,59,72,79-84]. Following image classification, map accuracy was assessed with a confusion matrix, which cross-tabulates independent validation data against mapped classes. The Kappa index of agreement was also used to quantify how much better than random the map was [85]. Map accuracy was further assessed using a geographically explicit grid, allowing for comparisons with existing maps and finer spatial WorldView-2 and Quickbird data to identify additional errors.

\subsection{Mangrove Carbon Stocks}

Using adaptations of methods proposed by the Centre for International Forestry Research (CIFOR) as described in Kauffman and Donato [86], carbon plots were systematically established within each mapped mangrove strata during a second field visit in August 2012. Several potential plots were eliminated from consideration in advance owing to their inaccessibility, proximity to class transitions, and/or map error. Carbon plots had a default size of $10 \times 10 \mathrm{~m}$ with dimensions doubled (i.e., $20 \times 20 \mathrm{~m}$ ) if needed to capture localized variability. Regardless of size, all were nested and comprised of an inner plot within a main plot. Within $5 \times 5 \mathrm{~m}$ or $10 \times 10 \mathrm{~m}$ inner plots (dependent on $10 \times 10 \mathrm{~m}$ or $20 \times 20 \mathrm{~m}$ dimensions of the main plot), all trees with a diameter $<5 \mathrm{~cm}$ were measured. Throughout the entire plot, all trees with a diameter $>5 \mathrm{~cm}$ were measured. Tree measurements included height, diameter, species type, and quality of lead stem from which plot-level density, stature, biomass, and species dominance were calculated. For standing dead trees and stumps, height and diameter were recorded to characterize the presence of natural and anthropogenic degradation. Seeds and saplings (i.e., regeneration), lying dead wood, leaf-litter, epiphytes, and under-story were also inventoried, but qualitatively, as their potential carbon stocks were thought to be negligible [87]. Canopy-cover was systematically measured in each plot to confirm and refine class definitions, and the geographic location was recorded using a Garmin GPSmap 62sc left averaging at the plot center. Soil depth was measured randomly in each plot quadrant to a depth of $3 \mathrm{~m}$ and soil samples were extracted at the plot-center using a cylindrical open-faced soil corer at depths of $0-15,15-30,30-50,50-100$, and 100-150 cm. In total, 51 carbon plots were established within mapped mangrove strata (Figure 2).

Following fieldwork, tree diameter and height measurements were used as input in allometric equations to calculate above-ground biomass and subsequently estimate carbon stocks. Equations were selected following a thorough review of the literature and expert advice (Table 2). The below-ground biomass of trees was calculated with a generalized equation presented in Komiyama et al. [88]. Carbon concentrations of 0.47 and 0.39 were used to convert live above- and below-ground biomass, respectively, to carbon mass $\left(\mathrm{Mg} \mathrm{Cha}^{-1}\right)$. The biomass of standing dead wood was calculated depending on assigned decay classes (Table 2) [86]. 
Table 2. Allometric equations employed for calculation of above-ground biomass (B) and additional equations used to estimate below-ground and standing dead wood biomass. Wood density $(\rho)$ values are taken from Simpson [89]. H, dbh, and D refer to tree height, diameter at breast height, and diameter, respectively.

\begin{tabular}{|c|c|c|c|c|}
\hline \multicolumn{5}{|c|}{ Live Above-Ground Biomass (AGB) } \\
\hline \multicolumn{2}{|c|}{ Species } & \multirow{2}{*}{ Equation } & \multirow{2}{*}{$\begin{array}{c}\rho \\
0.661\end{array}$} & \multirow{2}{*}{$\begin{array}{c}\text { Source } \\
\text { Dharmawan and Siregar (2008) } \\
{[90]}\end{array}$} \\
\hline $\begin{array}{c}\text { Avicennia } \\
\text { marina }\end{array}$ & & & & \\
\hline & (leaves) & $\mathrm{B}=0.0679 \times \mathrm{dbh}^{1.4914}$ & 0.741 & Clough \& Scott (1989) [91] \\
\hline $\begin{array}{c}\text { Bruguiera } \\
\text { gymnorrizha }\end{array}$ & (stem) & $\begin{aligned} \mathrm{B}=0.0464 \times & \left(\mathrm{dbh}{ }^{2} \times \mathrm{H}\right)^{0.94275} \\
& \times \rho\end{aligned}$ & 0.741 & $\begin{array}{c}\text { Kauffman \& Donato (2012) [86]; } \\
\text { Chave et al. (2005); [92] } \\
\text { Cole et al. (1999) [93] }\end{array}$ \\
\hline $\begin{array}{c}\text { Ceriops } \\
\text { tagal }\end{array}$ & $\begin{array}{c}\text { (dbh: } 2-18 \\
\mathrm{~cm}) \\
\text { (dbh: } 18-25 \\
\mathrm{~cm})\end{array}$ & $\begin{array}{l}\mathrm{B}=10^{-0.7247} \times \mathrm{dbh}^{2.3379} \\
\mathrm{~B}=10^{-0.494} \times \mathrm{dbh}^{2.056}\end{array}$ & 0.803 & $\begin{array}{c}\text { Clough \& Scott (1989) [91] } \\
\text { Comley \& McGuiness (2005) [94] }\end{array}$ \\
\hline & (leaves) & $\mathrm{B}=0.0679 \times \mathrm{dbh}^{1.4914}$ & 1.074 & Clough \& Scott (1989) [91] \\
\hline $\begin{array}{c}\text { Heritiera } \\
\text { littoralis }\end{array}$ & (stem) & $\begin{aligned} \mathrm{B}=0.0464 \times & \left(\mathrm{dbh}{ }^{2} \times \mathrm{H}\right)^{0.94275} \\
\times & \times \rho\end{aligned}$ & 1.074 & $\begin{array}{c}\text { Kauffman \& Donato (2012) [86]; } \\
\text { Chave et al. (2005); [92] } \\
\text { Cole et al. (1999) [93] }\end{array}$ \\
\hline $\begin{array}{c}\text { Lumnitzeria } \\
\text { racemosa }\end{array}$ & & $\begin{aligned} \mathrm{B}=0.0214 \times & \left(\mathrm{dbh}{ }^{2} \times \mathrm{H}\right)^{1.05655} \\
& \times \rho\end{aligned}$ & 0.565 & $\begin{array}{c}\text { Kauffman \& Donato (2012) [86]; } \\
\text { Chave et al. (2005); [92] } \\
\text { Cole et al. (1999) [93] }\end{array}$ \\
\hline & (leaves) & $\mathrm{B}=0.0139 \times \mathrm{D}^{2.1072}$ & 0.867 & Clough \& Scott (1989) [91] \\
\hline & (root) & $\mathrm{B}=0.0068 \times \mathrm{dbh}^{3.1353}$ & 0.867 & Clough \& Scott (1989) [91] \\
\hline mucronata & (stem) & $\begin{aligned} \mathrm{B}=0.0311 \times & \left(\mathrm{dbh}{ }^{2} \times \mathrm{H}\right)^{1.00741} \\
\times & \times \rho\end{aligned}$ & 0.867 & $\begin{array}{c}\text { Kauffman \& Donato (2012) [86]; } \\
\text { Chave et al. }(2005) ;[92] \\
\text { Cole et al. (1999) [93] }\end{array}$ \\
\hline $\begin{array}{l}\text { Sonneratia } \\
\text { alba }\end{array}$ & & $\begin{aligned} \mathrm{B}=0.0825 \times & \left(\mathrm{dbh}{ }^{2} \times \mathrm{H}\right)^{0.89966} \\
& \times \rho\end{aligned}$ & 0.78 & $\begin{array}{c}\text { Kauffman \& Donato (2012) [86]; } \\
\text { Chave et al. (2005); [92] } \\
\text { Cole et al. (1999) [93] }\end{array}$ \\
\hline $\begin{array}{c}\text { Xylocarpus } \\
\text { granatum }\end{array}$ & & $\begin{aligned} \mathrm{B}=0.0830 \times & \left(\mathrm{dbh}^{2} \times \mathrm{H}\right)^{0.89806} \\
& \times \rho\end{aligned}$ & 0.7 & $\begin{array}{c}\text { Kauffman \& Donato (2012) [86]; } \\
\text { Chave et al. (2005); [92] } \\
\text { Cole et al. (1999) [93] }\end{array}$ \\
\hline
\end{tabular}

Other Equations

Below-ground biomass:

Live and dead roots

Dead tree: Decay status 1

Dead tree: Decay status 2

$$
\mathrm{B}=0.199 \times \rho^{0.899} \times \mathrm{dbh}^{2.22}
$$

(where $\rho=$ species-specific wood density, as above)

$\mathrm{B}=0.975 \times \mathrm{AGB}$ $\mathrm{B}=0.8 \times \mathrm{AGB}$
Komiyama et al. (2005) [88]

Kauffman \& Donato (2012) [86]

Kauffman \& Donato (2012) [86]

$\mathrm{B}=$ biomass $(\mathrm{kg}), \mathrm{dbh}=$ diameter at breast height $(\mathrm{cm}), \mathrm{D}=$ diameter $(\mathrm{cm}), \mathrm{D}_{\text {top }}=$ diameter at top of stem $(\mathrm{cm})$, $\mathrm{D}_{\text {base }}=$ diameter at base of stem $(\mathrm{cm}), \mathrm{H}=$ height $(\mathrm{m})$, and $\rho=\operatorname{wood}$ density $\left(\mathrm{g} \mathrm{cm}^{-3}\right)$. 


\section{Results and Discussion}

\subsection{Overview of Existing Mangrove Coverage and Assessment of Long-Term Dynamics}

Comparisons of existing mangrove data-sets confirmed that national-level maps produced by the USGS (i.e., [58]) provided the most representative estimates of Mahajamba Bay's mangroves. The USGS maps focused solely on mangroves and provided reasonably contemporary (i.e., 2010) coverage. All other national-level maps represented multiple ecosystem types and time periods nearly or more than 10 years earlier. Further details regarding comparisons between Madagascar's existing national-level mangrove data-sets are available in Giri and Muhlhausen [57] and Jones et al. [56]. Analysis of the USGS maps indicated that from 1990 to 2000, Mahajamba Bays' mangroves decreased by 201 ha $(0.7 \%)$ and exhibited no detectable gain. In contrast, from 2000 to 2010, 1050 ha were lost $(3.8 \%)$ and 150 gained $(0.5 \%)$ (Figure 4$)$. Results suggest that the installation of substantial aquacultural infrastructure in the early 1990s (Figure 4: bottom center) by AQUALMA did not directly result in ha-level mangrove conversion (i.e., deforestation).

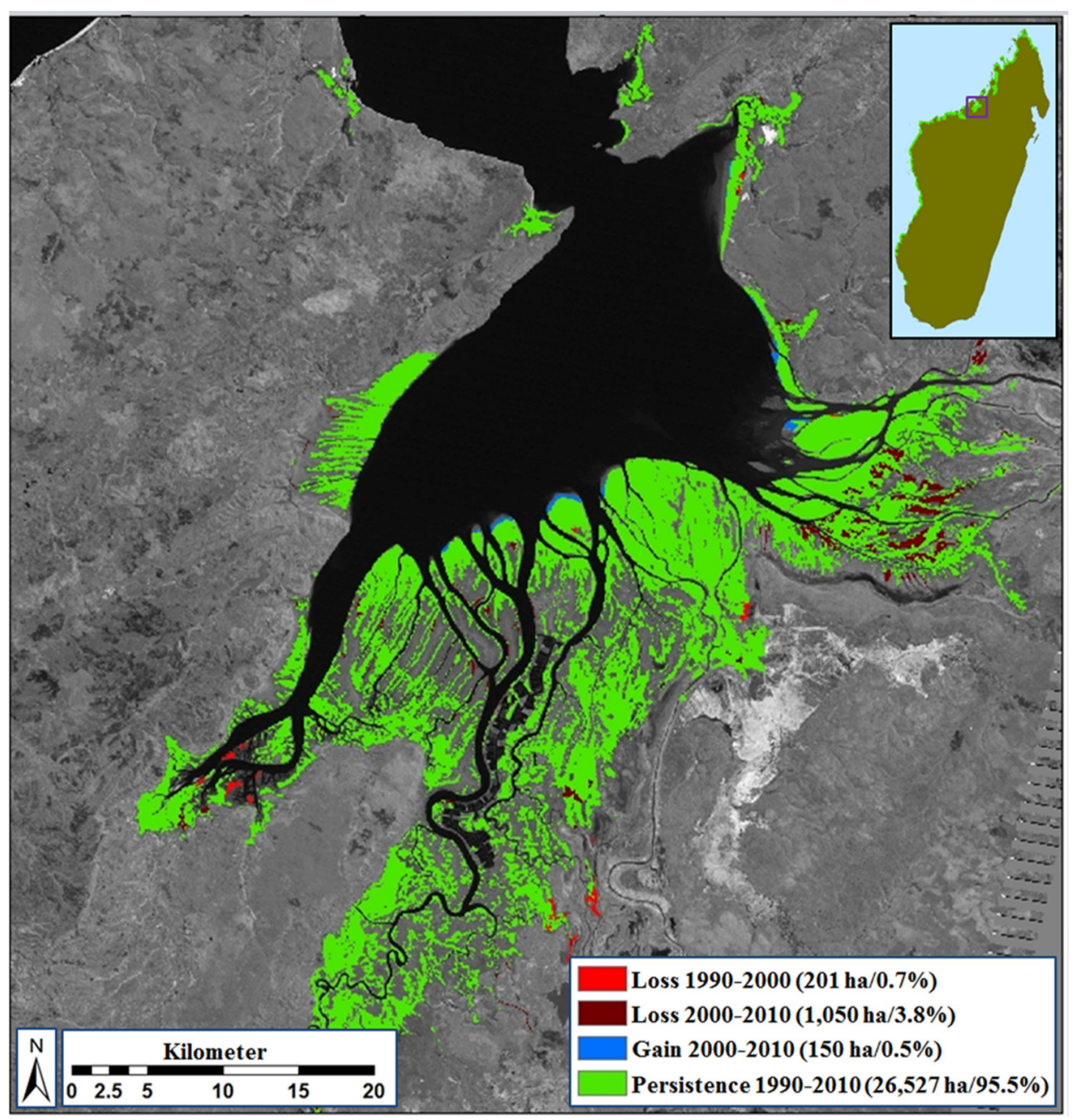

Figure 4. Dynamics (i.e., loss, gain, and persistence) in Mahajamba Bay's mangroves based on analysis of national-level Landsat-derived mangrove maps produced by the United States Geological Survey (USGS) [58]. The background image is Landsat 5 TM band 4. 
Compared with other primary mangrove ecosystems in Madagascar (e.g., Ambaro-Ambanja Bays, see Jones et al. [56]), Mahajamba Bay's mangroves have remained comparatively stable. Comparisons with terrestrial data (i.e., [66]) show that losses in the terrestrial forests surrounding Mahajamba Bay outpaced those of its mangroves from 1990 to 2000, and from 2000 to 2005 alone, terrestrial loss was greater than mangrove loss from 2000 to 2010. While lower than loss in surrounding terrestrial forests and comparatively lower than loss in other mangrove ecosystems, the deforestation of Mahajamba Bay's mangroves does appear to be increasing, occurring mainly in the east since 2000. Contextual socioeconomic research confirmed that five communes out of the six surrounding Mahajamba Bay exhibited potentially significant deforestation drivers (i.e., charcoal production and commercial timber exploitation). While extraction has traditionally been for self-consumption (e.g., building domiciles, boats, fencing), since 2000, commercial mangrove exploitation has increasingly contributed to deforestation. The growing demand from the nearby cities of Mahajanga and Sofia seems to be the primary contributor to the emergence of large-scale commercial timber exploitation in the eastern part of the Bay. In the south of the Bay, small-scale timber exploitation to supply rural towns prevails.

\subsection{Class Separability and Image Classification Results}

Results show that all mapped classes are spectrally separable using specific Landsat bands (Figure 5). In particular, the established spectral properties of vegetation in the near-infrared (NIR) and short-wave infrared (SWIR) were useful for differentiating between mangrove types, and for distinguishing mangroves from other mapped classes. In band $4(0.76-0.90$ micrometers $(\mu \mathrm{m}))$, the spectral separability of mangrove classes was likely driven by the variable reflectance in the NIR associated with the transitional red-edge, internal vegetation structure, and leaf dry-matter content $[15,53,95,96]$. In SWIR bands $5(1.55-1.75 \mu \mathrm{m})$ and $7(2.08-2.35 \mu \mathrm{m})$, differences in vegetation and soil moisture content and canopy-level biogeochemical constituents likely drove mangrove differentiation [97]. In addition to differentiation between mangrove types, these results support previous work demonstrating that the SWIR wavelengths help further differentiate mangroves from terrestrial vegetation [56,98]. Additional differences between mangrove types were also observed in visible bands 1 (i.e., blue: $0.45-0.52 \mu \mathrm{m}$ ), 2 (i.e., green: $0.53-0.61 \mu \mathrm{m}$ ), and 3 (i.e., red: $0.63-0.69 \mu \mathrm{m}$ ).

ML classification results indicate a total of 45,107 ha of mangroves within the AOI (Figure 6). Overall map accuracy was 98.6\% (Kappa 0.9), with all mangrove classes mapped with producer's and user's accuracies $\geq 90 \%$ (Table 3 ). While confusion with other vegetation classes (e.g., terrestrial forest types) has been reported as a common source of classification error [43], our results indicate that this was mostly avoided. Through comparison, it is clear that our classification results provide a more detailed and comprehensive representation of Mahajamba Bay than the single-class mangrove coverage provided by the USGS national-scale maps (Figure 7). While the USGS maps provide an unprecedented suite of multi-date mangrove coverage, they imply 27,202 ha of mangroves, leaving out upwards of 18,000 ha of mangroves which are either naturally lower stature or comparatively sparse due to degradation. This underrepresentation can exaggerate dynamics, as areas indicating loss may actually represent degraded mangroves. For instance, field observations indicate that some areas identified as deforested through analysis of the USGS maps were actually occupied by degraded mangroves reflecting the impact of cyclones. In addition, given their single-class nature, the USGS maps provide no context regarding 
surrounding land-cover categories, including areas that once were or could again become mangrove ecosystems (e.g., mud flats (i.e., tannes), represented by exposed soil/mud). Collectively, these shortcomings highlight the importance of conducting detailed localized mapping.

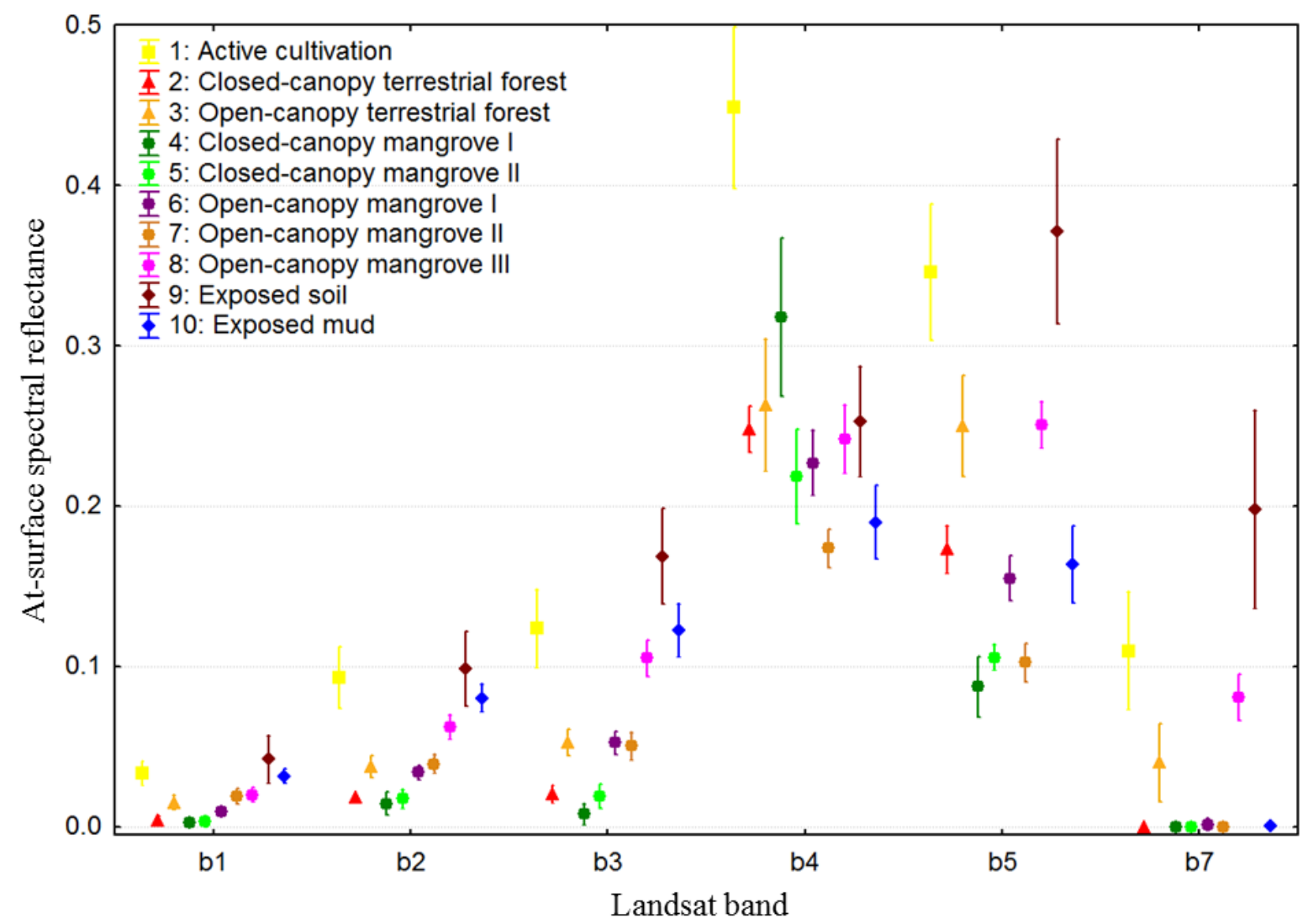

Figure 5. The mean spectral value ( \pm 1 standard deviation) of mapped categories.

Table 3. Results of accuracy assessment for classification of Landsat data.

\begin{tabular}{cccccccccccccc}
\hline & $\mathbf{1}$ & $\mathbf{2}$ & $\mathbf{3}$ & $\mathbf{4}$ & $\mathbf{5}$ & $\mathbf{6}$ & $\mathbf{7}$ & $\mathbf{8}$ & $\mathbf{9}$ & $\mathbf{1 0}$ & Total & User's (\%) & Commission (\%) \\
\hline Active cultivation (1) & 63 & 0 & 0 & 0 & 0 & 0 & 0 & 0 & 0 & 0 & 63 & 100 & 0 \\
Closed-canopy terrestrial forest (2) & 0 & 62 & 0 & 0 & 0 & 0 & 0 & 0 & 0 & 0 & 62 & 100 & 0 \\
Open-canopy terrestrial forest (3) & 0 & 1 & 72 & 0 & 0 & 3 & 0 & 1 & 0 & 0 & 77 & 94 & 6 \\
Closed-canopy mangrove I (4) & 0 & 0 & 0 & 90 & 2 & 0 & 0 & 0 & 0 & 0 & 92 & 98 & 2 \\
Closed-canopy mangrove II (5) & 0 & 0 & 0 & 0 & 88 & 0 & 0 & 0 & 0 & 0 & 88 & 100 & 0 \\
Open-canopy mangrove I (6) & 0 & 0 & 0 & 0 & 0 & 60 & 0 & 0 & 0 & 0 & 60 & 100 & 0 \\
Open-canopy mangrove II (7) & 0 & 0 & 0 & 0 & 0 & 0 & 60 & 0 & 0 & 0 & 60 & 100 & 0 \\
Open-canopy mangrove III (8) & 0 & 0 & 0 & 0 & 0 & 0 & 0 & 62 & 0 & 0 & 62 & 100 & 0 \\
Exposed soil (9) & 0 & 0 & 0 & 0 & 0 & 0 & 0 & 0 & 90 & 0 & 90 & 100 & 0 \\
Exposed mud (10) & 0 & 0 & 0 & 0 & 0 & 0 & 3 & 0 & 0 & 63 & 66 & 95 & 5 \\
Total & 63 & 63 & 72 & 90 & 90 & 63 & 63 & 63 & 90 & 63 & 720 & & \\
Producer's (\%) & 100 & 98 & 100 & 100 & 98 & 95 & 95 & 98 & 100 & 100 & & Overall & 98.6
\end{tabular}




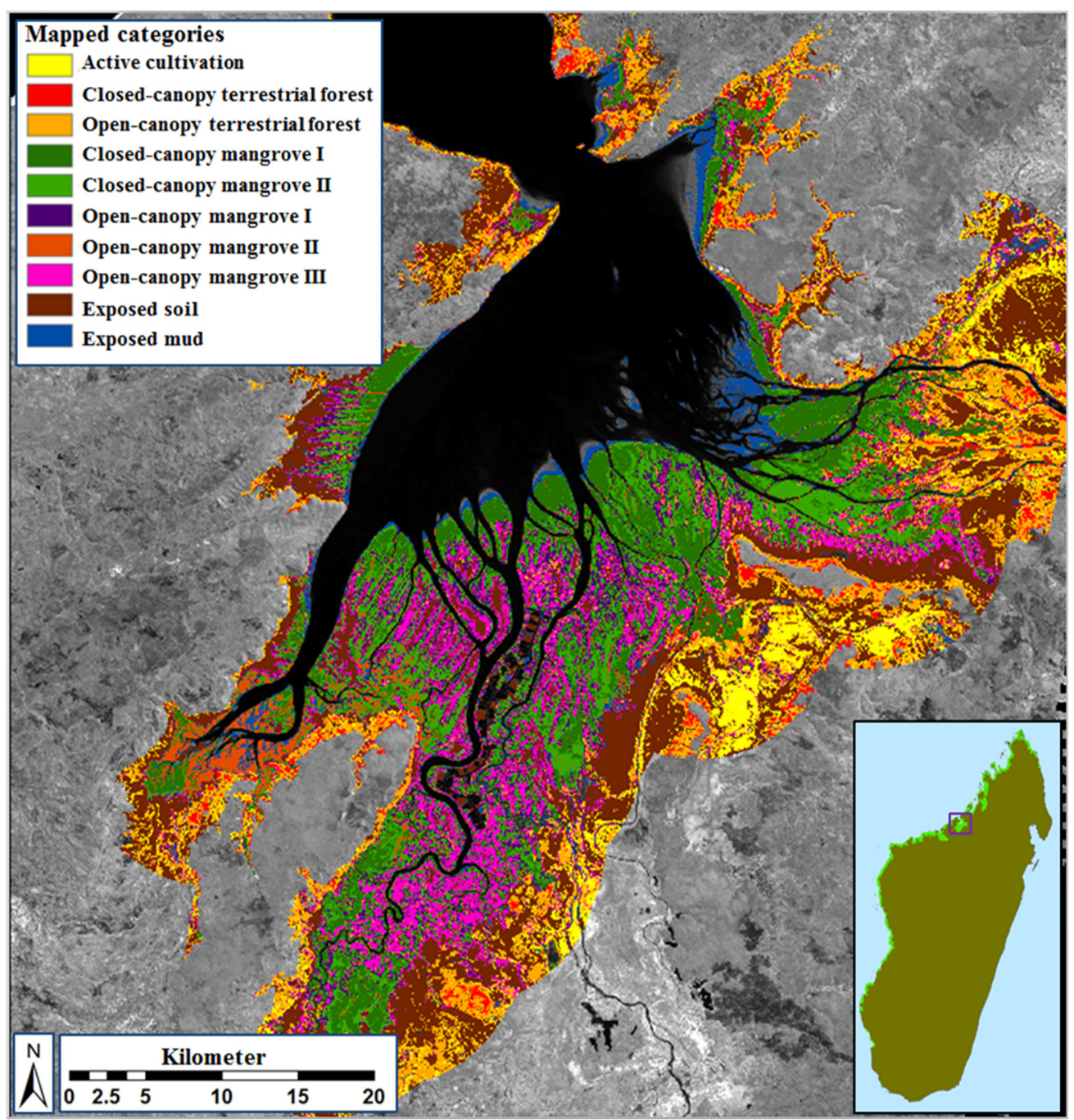

Figure 6. Classification results within the AOI, indicating 45,107 ha of mangroves distributed across five classes. The background image is Landsat 5 TM band 4.

\subsection{Ecological Characteristics of Mapped Mangrove Types}

Tree measurements summed at the plot-level allowed for summarizing the primary forest characteristics of mapped mangrove classes (Table 4). Open-canopy III plots were comprised of sparse and mostly stunted low stature shrub-dominated stands with very open canopies. Open-canopy I and II plots were primarily comprised of moderately-dense stands of medium stature trees with relatively open canopies. Closed-canopy I and II were typified by high stature trees exhibiting variable density but with well-formed closed canopies. Exceptions to these typical ecological characteristics include extremely dense medium/near-tall stands which can spectrally appear as closed-canopy I and/or II. In addition, stands dominated by mature trees, which were either naturally open and/or highly degraded, can spectrally appear as open-canopy I and/or II. At the landscape-level, there can be negligible spectral difference between areas comprised of relatively open-canopy medium stature trees and those comprised of tall trees which are naturally open, or have been heavily degraded. As such, while our field measurements confirm the distinct ecological characteristics of mapped classes, open-canopy classes can sometimes contain tall, mature stands which are either naturally very open or highly degraded. 


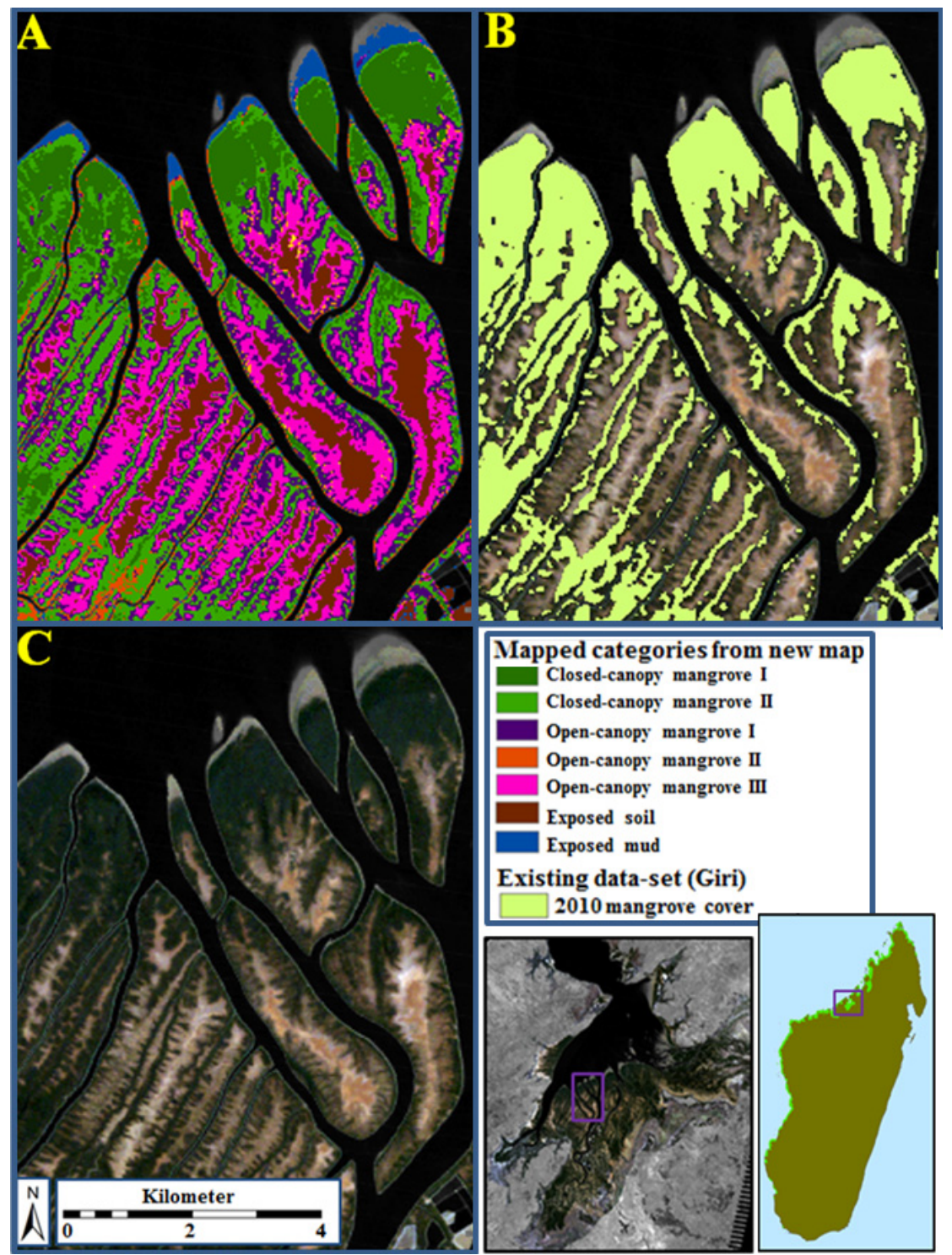

Figure 7. Classification results (panel A) compared with national-level USGS mangrove data [58] (panel B). A true color composite of Landsat bands 1, 2, and 3 is shown for context (panel $\mathbf{C}$ ) and as the background image (panels $\mathbf{A}, \mathbf{B}$ ). The under-representation of lower-stature, comparatively sparse mangroves and surrounding land-cover categories in the USGS data-set is shown in panel B.

Within all mangrove classes except open-canopy III, degradation was observed within some plots. The extent of natural versus anthropogenic degradation throughout the AOI remains uncertain, though inventories of standing dead trees in plots, which are indicative of the long-term influence of major disturbance events (e.g., cyclones), suggest natural degradation is more prevalent. Whether naturally induced or resulting from anthropogenic exploitation, accurately detecting and tracking subtle modification (i.e., degradation) remains a vexing challenge. The sub-pixel change in forest appearance is difficult to accurately measure using remotely sensed data of moderate spatial resolution (i.e., Landsat). While the use of finer spatial resolution imagery (e.g., WorldView-2 and QuickBird) holds much promise for distinguishing tree-level degradation, these data remain costly and can rarely provide wall-to-wall coverage over large areas for dates of interest. Exploring the fusion of other 
data-sets (e.g., radar; LiDAR) with readily available Landsat imagery holds particular promise, though access is also currently limited. With the additional explanatory power provided by fusing multiple data-sets, existing classes could be further partitioned to account for degradation. However, confidently differentiating between natural versus anthropogenic degradation would remain a challenge. Factoring in the mangrove class limitations, observations in our network of plots confirmed that these broad canopy-cover classes are spectrally distinct and ecologically rational. In addition, while mapping based on canopy closure is a major topic of research for terrestrial forests and previous studies have shown that extremely closed-canopies are associable with higher stature trees (e.g., [99]), our results contribute to what Heumann [43] summarizes as a comparative dearth of mangrove canopy-closure studies.

Table 4. Mangrove class, species dominance, average tree height \pm standard error (SE) (m), average $\mathrm{dbh} \pm \mathrm{SE}(\mathrm{cm})$, and average trees per hectare $\pm \mathrm{SE}$ (ha) for mapped mangrove categories.

\begin{tabular}{|c|c|c|c|c|c|c|c|}
\hline Class & Code & Description & $\begin{array}{c}\text { Species } \\
\text { Dominance }\end{array}$ & $N$ & $\begin{array}{c}\text { Average tree } \\
\text { height (m) }\end{array}$ & $\begin{array}{l}\text { Average dbh } \\
\qquad(\mathrm{cm})\end{array}$ & $\begin{array}{c}\text { Average } \\
\text { number of trees } \\
\left(\mathrm{ha}^{-1}\right)\end{array}$ \\
\hline \multirow{4}{*}{$\begin{array}{l}\text { Closed-canopy } \\
\text { mangrove I }\end{array}$} & \multirow{4}{*}{$\mathrm{CC} \mathrm{I}$} & \multirow{4}{*}{$\begin{array}{l}\text { Tall, mature stands of trees; } \\
\text { canopy }>80 \% \text { closed }\end{array}$} & A. marina & 7 & $10.24 \pm 0.52$ & $13.68 \pm 1.01$ & $1571 \pm 255$ \\
\hline & & & R. mucronata & 2 & $5.62 \pm 0.55$ & $7.27 \pm 1.69$ & $4900 \pm 1500$ \\
\hline & & & S. alba & 1 & 9.39 & 8.31 & 5100 \\
\hline & & & Mixed species & 3 & $12.48 \pm 1.40$ & $18.18 \pm 1.56$ & $1108 \pm 208$ \\
\hline Closed-canopy & & Tall mature stands of trees; & A. marina & 10 & $7.68 \pm 0.56$ & $12.95 \pm 1.26$ & $895 \pm 102$ \\
\hline mangrove II & & canopy $>60 \%$ closed & Mixed species & 2 & $7.74 \pm 0.04$ & $12.45 \pm 0.08$ & $1412 \pm 12$ \\
\hline \multirow{3}{*}{$\begin{array}{l}\text { Open-canopy } \\
\text { mangrove I }\end{array}$} & \multirow{3}{*}{ OC I } & Short-medium stands of & A. marina & 6 & $3.32 \pm 0.16$ & $4.85 \pm 0.43$ & $1417 \pm 226$ \\
\hline & & $30-70 \%$ closed; moderately & $X$. granatum & 1 & 5.41 & 10.84 & 1300 \\
\hline & & $\begin{array}{l}\text { influenced by background } \\
\text { soil/mud }\end{array}$ & Mixed species & 5 & $4.33 \pm 0.44$ & $7.62 \pm 0.86$ & $1185 \pm 237$ \\
\hline \multirow{2}{*}{$\begin{array}{l}\text { Open-canopy } \\
\text { mangrove II }\end{array}$} & \multirow[b]{2}{*}{ OC II } & $\begin{array}{c}\text { Short-medium stands of } \\
\text { trees/shrubs; canopy }\end{array}$ & C. tagal & 2 & $3.39 \pm 0.18$ & $6.18 \pm 0.12$ & $963 \pm 238$ \\
\hline & & $\begin{array}{c}\text { 30-70\% closed; significantly } \\
\text { influenced by background } \\
\text { soil/mud }\end{array}$ & R. mucronata & 4 & $4.63 \pm 0.30$ & $7.85 \pm 1.66$ & $1388 \pm 449$ \\
\hline \multirow[t]{2}{*}{$\begin{array}{l}\text { Open-canopy } \\
\text { mangrove III }\end{array}$} & \multirow[t]{2}{*}{ OC III } & $\begin{array}{l}\text { Stunted, short stands, shrub- } \\
\text { dominated, very sparse; canopy } \\
<30 \% \text { closed; dominated by }\end{array}$ & A. marina & 7 & $2.31 \pm 0.17$ & $3.96 \pm 0.18$ & $1089 \pm 134$ \\
\hline & & exposed soil/mud & & & & & \\
\hline
\end{tabular}

\subsection{Carbon Stock Estimates of Mapped Mangrove Types}

Estimates of carbon calculated based on measurements within 51 systematically sampled plots were scaled to the hectare level (Table 5, Figures 2 and 8). Total vegetation (i.e., above- and below-ground) carbon stock estimates, which varied from 2.97 to $279.49 \mathrm{Mg} \mathrm{C} \mathrm{ha}^{-1}$, reflect the changes in stature through the classes with the highest carbon values observed within the closed-canopy I class $\left(166.82 \pm 15.38 \mathrm{Mg} \mathrm{C} \mathrm{ha}^{-1}\right)$, where tree stature is largest and tree density is highest. Conversely, the 
lowest carbon values were observed where stature and density was lowest, within the open-canopy III mangrove class $\left(20.66 \pm 6.61 \mathrm{Mg} \mathrm{Cha}^{-1}\right)$. Within all classes, above-ground carbon constituted the largest proportion of total vegetation carbon stocks, ranging from $50 \%$ (open-canopy I) to $66 \%$ (closed-canopy I). The contribution of dead biomass to total carbon stocks ranged from $1.46 \%$ to $38 \%$ with the highest proportion of dead biomass observed in open-canopy I mangroves. The overall mean carbon stock estimation for all mangrove classes combined was $100.96 \pm 10.49 \mathrm{Mg} \mathrm{C} \mathrm{ha}^{-1}$.

Table 5. Mean hectare (ha)-level estimates of above- and below-ground carbon $\pm \mathrm{SE}$ $\left(\mathrm{Mg} \mathrm{Cha}^{-1}\right)$ for live and dead trees.

\begin{tabular}{|c|c|c|c|c|c|c|}
\hline \multirow{2}{*}{$\begin{array}{l}\text { Mangrove } \\
\text { class }\end{array}$} & \multirow[t]{2}{*}{$N$} & \multicolumn{2}{|c|}{$\begin{array}{l}\text { Above-ground vegetation carbon } \\
\left(\mathrm{Mg} \mathrm{C} \mathrm{ha}^{-1}\right)\end{array}$} & \multicolumn{2}{|c|}{$\begin{array}{c}\text { Below-ground vegetation } \\
\text { carbon }\left(\mathrm{Mg} \mathrm{C} \mathrm{ha}^{-1}\right) \\
\end{array}$} & \multirow{2}{*}{$\begin{array}{c}\text { Total vegetation } \\
\text { carbon }\left(\mathrm{Mg} \mathrm{C} \mathrm{ha}^{-1}\right)\end{array}$} \\
\hline & & Live & Dead & Live & Dead & \\
\hline $\mathrm{CC} \mathrm{I}$ & 13 & $104.54 \pm 11.23$ & $5.16 \pm 1.55$ & $50.07 \pm 5.56$ & $7.05 \pm 1.86$ & $166.82 \pm 15.38$ \\
\hline CC II & 12 & $88.50 \pm 9.77$ & $13.66 \pm 2.66$ & $38.82 \pm 4.07$ & $15.80 \pm 3.05$ & $156.77 \pm 15.98$ \\
\hline OC I & 13 & $22.45 \pm 3.45$ & $7.27 \pm 1.93$ & $13.69 \pm 2.51$ & $15.72 \pm 4.24$ & $59.13 \pm 9.48$ \\
\hline OC II & 6 & $17.66 \pm 6.53$ & $0.12 \pm 0.06$ & $12.90 \pm 4.14$ & $0.33 \pm 0.18$ & $31.01 \pm 10.55$ \\
\hline OC III & 7 & $9.68 \pm 2.72$ & $2.54 \pm 1.1$ & $4.87 \pm 1.38$ & $3.57 \pm 1.55$ & $20.66 \pm 6.61$ \\
\hline
\end{tabular}

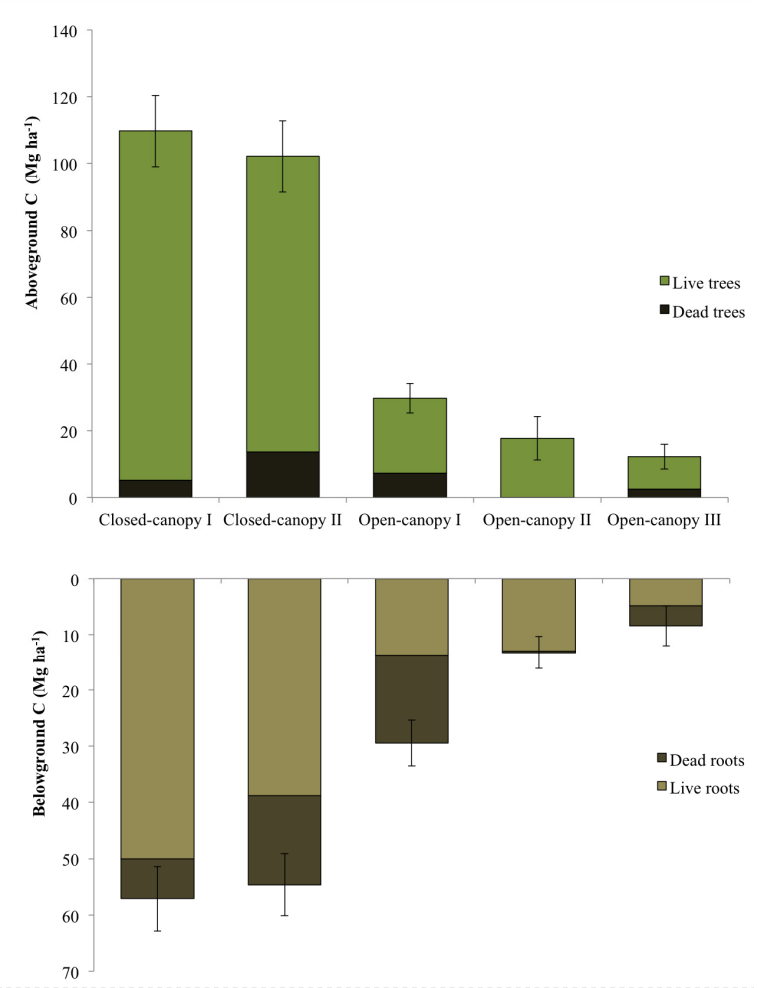

Figure 8. Above- and below-ground vegetation carbon stocks for each mangrove class in Mahajamba Bay. Error bars indicate \pm SE. Note the varying scale of the $y$-axes above- and below-ground. 
$\mathbf{A}$
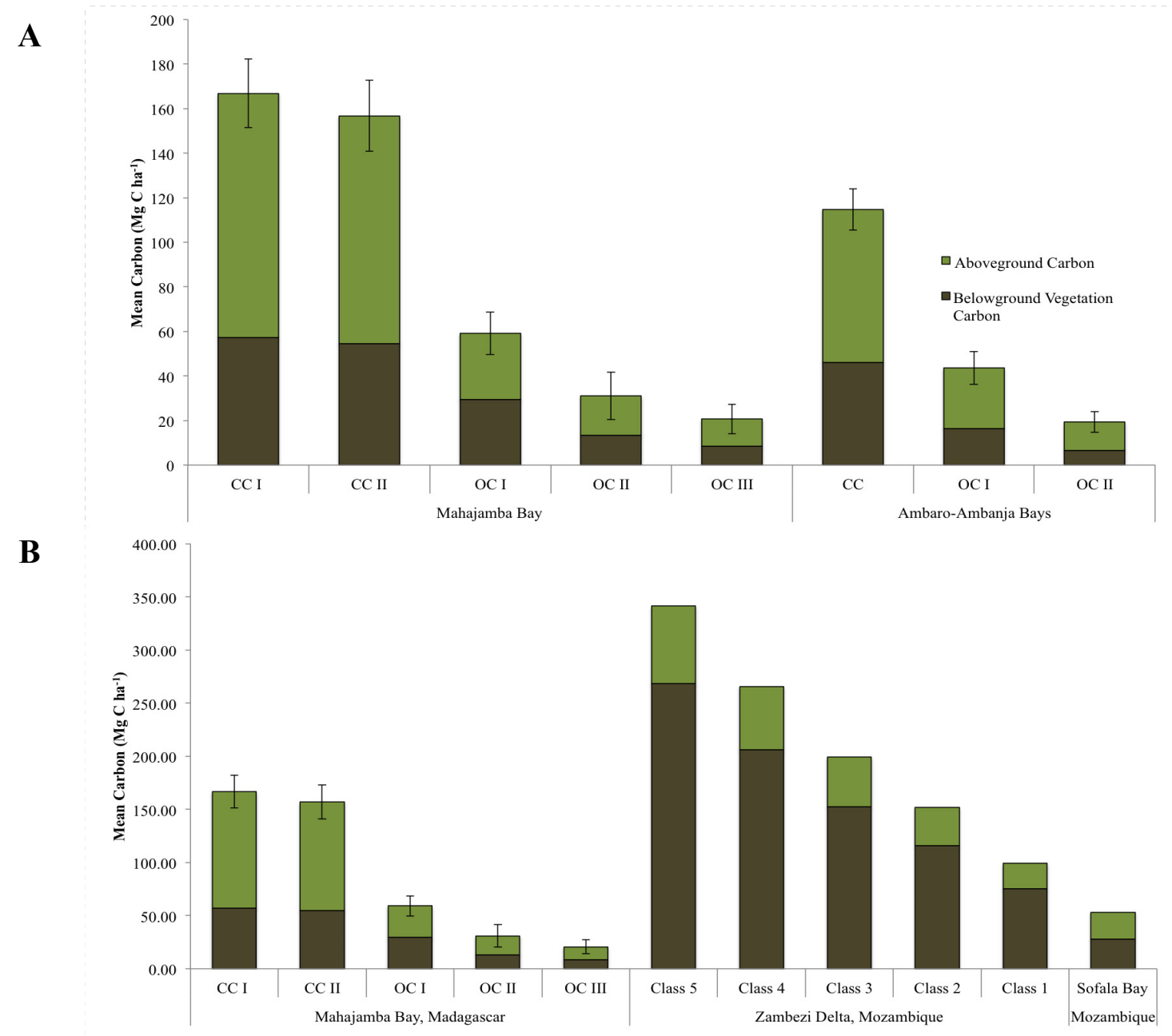

C

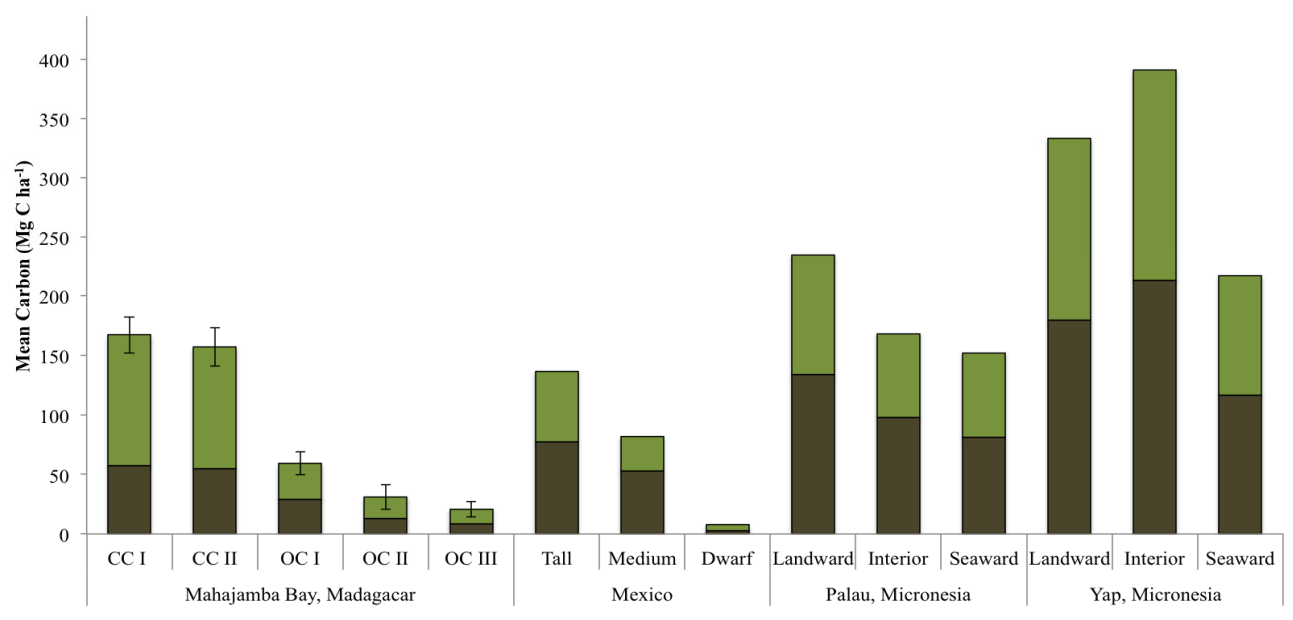

Figure 9. Vegetation carbon stock estimations for Mahajamba Bay, Madagascar compared with other published carbon stocks (A) within Madagascar: Ambaro-Ambanja Bays (adapted from [100], with permission from (C) 2015 Springer); (B) within the Western Indian Ocean: Zambezi Delta (adapted from [101], with permission from (C) 2014 USFS) and Sofala Bay (adapted from [37], with permission from (C) 2014 MDPI); and (C) across the globe: Mexico (adapted from [102], with permission from (C) 2011 Public Library of Sciene), and two regions in Micronesia: Palau and Yap adapted from [87], with permission from (C) 2011 Springer). Error bars on Mahajamba data indicate \pm SE. 
When comparing to other mangroves in Madagascar (i.e., Ambaro-Ambanja Bays), vegetation carbon stocks within the closed-canopy classes were observed to be higher in Mahajamba Bay (156.77-166.82 $\mathrm{Mg} \mathrm{C} \mathrm{ha}^{-1}$ ) than in Ambaro-Ambanja Bays (114.8 $\pm 9.3 \mathrm{Mg} \mathrm{C} \mathrm{ha}^{-1}$, [100], Figure 9A). This can be explained by a disproportionate prevalence of higher stature trees in Mahajamba Bay, which is likely influenced by a comparatively greater distance from the sea. In contrast, the similar ecological characteristics of the open-canopy classes were reflected in their comparable carbon stock estimations.

Across East Africa, mangrove species composition and zonation follow similar patterns, which is reflected in comparable carbon stock estimates (Figure 9B). Throughout Mozambique, mean carbon stock estimates have been found to vary greatly [72] from the high stature forests of the Zambezi River Delta (99.0-341.3 $\mathrm{Mg} \mathrm{C} \mathrm{ha}^{-1}$, [101]) to the smaller stature forests of Sofala Bay (53.2 $\mathrm{Mg} \mathrm{C} \mathrm{ha}^{-1}$, [37]). The estimated vegetation carbon stocks of Mahajamba Bay fall within the range of the Mozambique data, with the observed variances most likely a result of differences in forest stature across classes and study areas.

Greater variation was observed when comparing vegetation carbon stocks with mangroves outside of the Western Indian Ocean, which was likely due to environmental variability over greater spatial scales. Carbon stock estimates for Mexico as described in Adame et al. [102] appeared lower $\left(31.9 \pm 10.9 \mathrm{Mg} \mathrm{C} \mathrm{ha}^{-1}\right)$ than those of Mahajamba Bay (Figure 9C). In western Micronesia, mangrove C storage ranged from 151 (seaward) to 233 (landward) $\mathrm{Mg} \mathrm{C} \mathrm{ha}^{-1}$ in Yap state (Federated States of Micronesia) and from 216 (seaward) to 331 (landward) $\mathrm{Mg} \mathrm{C} \mathrm{ha}^{-1}$ in the Republic of Palau [87].

While these results contribute to numerous studies which have estimated the above- and below-ground biomass of mangrove trees (e.g., [17,18,37,103-127]), the soil stores most of the carbon in mangrove ecosystems and thus soil carbon is important to include in further analyses [14,56,86,87,99,111-124]. Until very recently, existing soil analysis facilities in Madagascar were only able to provide soil organic carbon (SOC) results based on the conservative Walkley-Black (WB) methodology [89,128-131]. As of January 2015, a new soil analysis lab capable of undertaking loss on ignition (LOI) is operational at the University of Antananarivo. Once LOI analysis of samples extracted from all plots as described in this study is complete, results are expected to build on previous studies [56,100] which conservatively demonstrate the high SOC content for Madagascar's mangroves.

\section{Conclusions}

Our contemporary map provides detailed and accurate coverage of mangrove types and surrounding land-cover categories, closing a temporal gap and offering numerous improvements over existing data-sets. This contemporary map facilitated partitioning Mahajamba Bay's mangroves in an ecologically meaningful manner and systematically sampling carbon stocks. While the carbon stock estimates presented in this study are limited to above- and below-ground vegetation, they are consistent with other regional estimates and demonstrate the significance of Mahajamba Bay toward climate change mitigation. With new soil analysis facilities operational at the University of Antananarivo, the completed analysis of our soil samples is expected to drastically increase these estimates. Collectively, these results support ongoing initiatives investigating the feasibility of mangrove carbon financing projects and other payments for ecosystem services (PES) schemes. 
While deforestation is increasing in Mahajamba Bay, net loss is less than in many of Madagascar's other mangrove ecosystems. However, drivers leading to widespread deforestation elsewhere (e.g., charcoal production, timber extraction) are increasingly evident. The continuation and acceleration of this loss will compromise if not discontinue many critical ecosystem services. In addition, there is great risk for ripple effects which negatively influence surrounding and closely linked marine and terrestrial ecosystems. Intervention is required to avoid the rapid depletion of mangroves experienced in other Madagascan forests such as the Ambaro-Ambanja Bay complex (see Jones et al. [100]), where about 1653 ha of mangrove were lost between 2000 and 2010, mainly as a result of overexploitation for charcoal production. The first step toward mitigating mangrove deforestation is quantifying the extent of and contextualizing the reasons for and consequences of loss. Here, we have advanced this agenda by quantifying and contextualizing dynamics, and presenting a contemporary localized map of ecologically meaningful mangrove types and their carbon stock estimates.

\section{Acknowledgments}

This research was funded by grants from the Western Indian Ocean Marine Science Association and the John D. and Catherine T. MacArthur Foundation. The authors greatly appreciate the logistical support for field work provided by AQUALMA. Thanks to Lilian Mwihaki (Kenya Marine and Fisheries Research Institute) for assistance with adapting field techniques and undertaking carbon stock measurements. Additional thanks also to Kate England (Blue Ventures) for socio-economic context and to Holy Andriamitantsoa and Tina Haingonirina (University of Toliara: Institute of Fisheries and Marine Science) for contributions towards field missions. Additional thanks to two extremely helpful anonymous reviewers.

\section{Author contributions}

Jones took the lead on designing and undertaking the dynamics assessment, contemporary mapping, ecological characterization and carbon stock inventory and on writing the manuscript. Rakoto Ratsimba helped design and assisted with oversight of field missions, the dynamics assessment and contemporary mapping. Ravaoarinorotsihoarana helped design, lead and summarize data resulting from field missions, and further helped with carbon stock estimates. Glass assisted with the dynamics assessment, contemporary mapping and carbon stock estimates, and helped provide oversight for the manuscript. Benson and Teoh assisted with carbon stock estimates. Cripps helped provide oversight on the conception and design of the carbon stock inventory and socio-economic research. Carro led on the analysis and summary of socio-economic research. Giri assisted with the dynamics assessment and contemporary mapping. Gandhi assisted with geospatial data pre-processing, the dynamics assessment, contemporary mapping and formatting the manuscript. Andriamahenina helped lead field teams during both ecological and carbon stock inventories, and helped ensure all data were collected, entered, summarized and prepared for mapping and carbon stock estimates. Rakotomanana and Roy helped design and lead socio-economic research in the field. 


\section{Conflicts of Interest}

The authors declare no conflict of interest.

\section{References}

1. Lugo, A.E.; Snedaker, S.C. The ecology of mangroves. Annu. Rev. Ecol. Syst. 1974, 5, 39-64.

2. Blasco, F.; Bellan, M.F.; Chaudhury, M.U. Estimating the extent of floods in Bangladesh-Using SPOT data. Remote Sens. Environ. 1992, 39, 167-178.

3. Marshall, N. Mangrove conservation in relation to overall environmental considerations. Hydrobiologia 1994, 285, 303-309.

4. Primavera, J.H. Socio-economic impacts of shrimp culture. Aquac. Res. 1997, 28, 815-827.

5. Kathiresan, K.; Bingham, B. Biology of mangroves and mangrove ecosystems. Adv. Mar. Biol. 2001, 40, 81-251.

6. Alongi, D.M. Present state and future of world's mangrove forest. Environ. Conserv. 2002, 29, 331-349.

7. Mumby, P.J.; Edwards, A.J.; Arias-Gonzáles, E.; Lindeman, K.C.; Blackwell, P.G.; Gall, A.; Gorczynska, M.I.; Harborne, A.R.; Pescod, C.L.; Renken, H.; et al. Mangrove enhance the biomass of coral reef fish communities in the Caribbean. Nature 2004, 427, 533-536.

8. Dahdouh-Guebas, F.; Jayatissa, L.P.; di Nitto, D.; Bosire, J.O.; Lo Seen, D.; Koedam, N. How effective were mangroves as a defence against the recent tsunami? Curr. Biol. 2005, 15, R443-R447.

9. Barbier, E.B. Natural barriers to natural disasters: Replanting mangroves after tsunami. Front. Ecol. Environ. 2006, 4, 124-131.

10. Food and Agricultural Organization (FAO). The World's Mangroves 1980-2005; FAO: Rome, Italy, 2007; p. 153.

11. Alongi, D.M. Mangrove forests: Resilience, protection from tsunamis, and responses to global climate change. Estuar. Coast. Shelf Sci. 2008, 76, 1-13.

12. Nagelkerken, I.; Blaber, S.J.; Bouillon, S.; Green, P.; Haywood, M.; Kirton, L.G.; Meynecke, J.-O.; Pawlik, J.; Penrose, H.M.; Sasekumar, A.; et al. The habit function of mangroves for terrestrial and marine fauna: A review. Aquat. Bot. 2008, 89, 155-185.

13. Alongi, D.M. Carbon payments for mangrove conservation: Ecosystem constraints and uncertainties of sequestration potential. Environ. Sci. Policy 2011, 14, 462-470.

14. Donato, D.C.; Kauffman, J.B.; Murdiyarso, D.; Kumianto, S.; Stidham, M.; Kanninen, M. Mangroves among the most carbon-rich forests in the tropics. Nat. Geosci. 2011, 4, 293-297.

15. Kuezner, C.; Bluemel, A.; Gebhardt, S.; Quoc, T.V.; Dech, S. Remote sensing of mangrove ecosystems: A review. Remote Sens. 2011, 3, 878-928.

16. Pendleton, L.; Donato, D.C.; Murray, B.C.; Crooks, S.; Jenkins, W.A.; Sifleet, S.; Craft, C.; Fourqurean, J.W.; Kauffman, J.B.; Marba, N.; et al. Estimating global "blue carbon" emissions from conversion and degradation of vegetated coastal ecosystems. PLoS ONE 2012, 7, e43542.

17. Kauffman, J.B.; Heider, C.; Norfolk, J.; Payton, F. Carbon stocks of intact mangroves and carbon emissions arising from their conversion in the Dominican Republic. Ecol. Appl. 2014, 24, 518-527. 
18. Thompson, B.S.; Clubbe, C.P.; Primavera, J.H.; Curnick, D.; Koldeway, H.J. Locally assessing the economic viability of blue carbon: A case study from Panay Island, the Philippines. Ecosyst. Serv. 2014, 8, 128-140.

19. Giri, C.; Long, J.; Abbas, S.; Mani Murali, R.; Qamer, F.M.; Pengra, B.; Thau, D. Distribution and dynamics of mangrove forests of South Asia. J. Environ. Manag. 2015, 148, 101-111.

20. Huxham, M.; Emerton, L.; Kairo, J.; Munyi, F.; Abdirizak, H.; Muriuki, T.; Nunan, F.; Briers, R.A. Applying Climate Compatible Development and economic valuation to coastal management: A case study of Kenya's mangrove forests. J. Environ. Manag. 2015, 157, 168-181.

21. Valiela, I.; Bowen, J.L.; York, J.K. Mangrove forests: One of the world's threatened major tropical environments. Bioscience 2001, 51, 807-815.

22. Duke, N.C.; Meynecke, J.O.; Dittmann, S.; Ellison, A.M.; Anger, K.; Berger, U.; Cannicci, S.; Diele, K.; Ewel, K.C.; Field, C.D.; et al. A world without mangroves? Science 2007, 317, 41-42.

23. Spalding, M.; Kainuma, M.; Collins, L. World Atlas of Mangroves; Earthscan: London, UK, 2010.

24. Friess, D.A.; Webb, E.L. Variability in mangrove change estimates and implications for the assessment of ecosystem provision. Glob. Ecol. Biogeogr. 2013, 23, 715-725.

25. Alongi, D.M. The Impact of Climate Change on Mangrove Forests. Curr. Clim. Chang. Rep. 2015, $1,30-39$.

26. Polidoro, B.A.; Carpenter, K.E.; Collins, L.; Duke, N.C.; Ellison, A.M.; Ellison, J.C.; Farnsworth, E.J.; Fernando, E.S.; Kathiresan, K.; Koedam, N.E.; et al. Mangrove extinction risk and geographic areas of global concern. PLoS ONE 2010, 5, e10095.

27. Daru, B.H.; Yessoufou, K.; Mankga, L.T.; Davies, J. A Global Trend towards the Loss of Evolutionarily Unique Species in Mangrove Ecosystems. PLoS ONE 2013, 8, 1-9.

28. Farnsworth, E.J.; Ellison, A.M. The global conservation status of mangroves. AMBIO 1997, 26, $328-334$.

29. Primavera, J.H. Development and conservation of Philippine mangroves: Institutional issues. Ecol. Econ. 2000, 35, 91-106.

30. Dahdouh-Guebas, F. The use of remote sensing and GIS in the sustainable management of tropical coastal ecosystems. Environ. Dev. Sustain. 2002, 4, 93-112.

31. Primavera, J.H. Mangroves, fishponds, and the quest for sustainability. Science 2005, 310, 57-59.

32. Gopal, B.; Chauhan, M. Biodiversity and its conservation in the Sundarban Mangrove Ecosystem. Aquat. Sci. 2006, 68, 338-354.

33. Primavera, J.H. Overcoming the impacts of aquaculture on the coastal zone. Ocean Coast. Manag. 2006, 49, 531-545.

34. Gilman, E.L.; Ellison, J.; Duke, N.C.; Field, C. Threats to mangroves from climate change and adaptation options: A review. Aquat. Bot. 2008, 89, 237-250.

35. Walters, B.B.; Rönnbäck, P.; Kovacs, J.M.; Crona, B.; Hussain, S.A.; Badola, R.; Primavera, J.H.; Barbier, E.; Dahdouh-Guebas, F. Ethnobiology, socio-economics and management of mangrove forests: A review. Aquat. Bot. 2008, 89, 220-236.

36. Webb, E.L.; Jachowski, N.R.A.; Phelps, J.; Friess, D.A.; Than, M.M.; Ziegler, A.D. Deforestation in the Ayeyarwady Delta and the conservation implications of an internationally-engaged Myanmar. Glob. Environ. Chang. 2014, 24, 321-333. 
37. Sitoe, A.A.; Mandlate, L.J.C.; Guedes, B.S. Biomass and Carbon Stocks of Sofala Bay Mangrove Forests. Forests 2014, 5, 1967-1981.

38. Field, C.D. Impact of expected climate change on mangroves. Hydrobiologia 1995, 295, 75-81.

39. Krauss, K.W.; Lovelock, C.E.; McKee, K.L.; Lopez-Hoffman, L.; Ewe, S.M.L.; Sousa, W.P. Environmental drivers in mangrove establishment and early development: A review. Aquat. Bot. 2008, 89, 105-127.

40. Chan, H.T.; Baba, S. Manual on Guidelines for Rehabilitation of Coastal Forests Damaged by Natural Hazards in the Asia-Pacific Region; International Society for Mangrove Ecosystems (ISME) and International Tropical Timber Organization (ITTO): Okinawa, Japan, 2009; p. 66.

41. Suzuki, T.; Zijlema, M.; Burger, B.; Meijer, M.C.; Narayan, S. Wave dissipation by vegetation with layer schematization in SWAN. Coast. Eng. 2012, 59, 64-71.

42. Di Nitto, D.; Neukermans, G.; Koedman, N.; Defever, H.; Pattyn, F.; Kairo, J.G.; Dahdouh-Guebas, F. Mangroves facing climate change: landward migration potential in response to projected scenarios of sea level rise. Biogeosciences 2014, 11, 857-871.

43. Heumann, B.W. Satellite remote sensing of mangrove forests: Recent advances and future opportunities. Prog. Phys. Geogr. 2011, 35, 87-108.

44. Manson, F.J.; Loneragan, N.R.; McLeod, I.M.; Kenyon, R.A. Assessing techniques for estimating the extent of mangroves: Topographic maps, aerial photographs, and Landsat TM images. Mar. Freshw. Res. 2001, 52, 787-792.

45. Ruiz-Luna, A.; Berlanga-Robles, C.A. Land use, land cover changes and coastal lagoon surface reduction associated with urban growth in northwest Mexico. Landsc. Ecol. 2003, 18, 159-171.

46. Cornejo, R.H.; Koedam, N.; Luna, A.R.; Troell, M.; Dahdouh-Guebas, F. Remote sensing and ethno- botanical assessment of the mangrove forest changes in the Navachiste-San Ignacio-Macapule lagoon complex, Sinaloa, Mexico. Ecol. Soc. 2005, 10, 16.

47. Beland, M.; Goita, K.; Bonn, F.; Pham, T.T.H. Assessment of land-cover changes related to shrimp aquaculture using remote sensing data: A case study in the Giao Thuy District, Vietnam. Int. J. Remote Sens. 2006, 27, 1491-1510.

48. Giri, C.; Pengra, B.; Zhu, Z.L.; Singh, A.; Tieszen, L.L. Monitoring mangrove forest dynamics of the Sundarbans in Bangladesh and India using multi-temporal satellite data from 1973 to 2000. Estuar. Coast. Shelf Sci. 2007, 73, 91-100.

49. Giri, C.; Zhu, Z.; Tieszen, L.L.; Singh, A.; Gillette, S.; Kelmelis, J.A. Mangrove forest distributions and dynamics (1975-2005) of the tsunami-affected region of Asia. J. Biogeogr. 2008, 35, 519-528.

50. Liu, K.; Li, X.; Shi, X.; Wang, S.G. Monitoring mangrove forest changes using remote sensing and GIS data with decision-tree learning. Wetlands 2008, 28, 336-346.

51. Paling, E.I.; Kobryn, H.T.; Humphreys, G. Assessing the extent of mangrove change caused by Cyclone Vance in the eastern Exmouth Gulf, northwestern Australia. Estuar. Coast. Shelf Sci. 2008, 77, 603-613.

52. Giri, C.; Ochieng, E.; Tieszen, L.L.; Zhu, Z.; Singh, A.; Loveland, T.; Masek, J.; Duke, N. Status and distribution of mangrove forests of the world using earth observation satellite data. Glob. Ecol. Biogeogr. 2011, 20, 154-159.

53. Alsaaideh, B.; Al-Hanbali, A.; Tateishi, R.; KoBayashi, T.; Hoan, N.T. Mangrove forests mapping in the southern part of Japan using Landsat ETM+ with DEM. J. Geogr. Inf. Syst. 2013, 5, 369-377. 
54. Li, M.S.; Mao, L.J.; Shen, W.J.; Liu, S.Q.; Wei, A.I. Change and fragmentation trends of Zhanjiang mangrove forests in southern China using multi-temporal Landsat imagery (1977-2010). Estuar. Coast. Shelf Sci. 2013, 130, 111-120.

55. Nguyen, H.; McAlpine, C.; Pullar, D.; Johansen, K.; Duke, N. The relationship of spatial-temporal changes in fringe mangrove extent and adjacent land-use: Case study of Ken Giang coast, Vietnam. Ocean Coast. Manag. 2013, 76, 12-22.

56. Jones, T.G.; Ratsimba, H.R.; Ravaoarinorotsihoarana, L.; Cripps, G.; Bey, A. Ecological Variability and Carbon Stock Estimates of Mangrove Ecosystems in Northwestern Madagascar. Forests 2014, 5, 177-205.

57. Giri, C.; Muhlhausen, J. Mangrove forest distributions and dynamics in Madagascar (1975-2005). Sensors 2008, 8, 2104-2117.

58. Giri, C. National-Level Mangrove Cover Data-Sets for 1990, 2000 and 2010; United States Geological Survey: Sioux Falls, SD, USA, 2011.

59. Rasolofoharinoro, M.; Blasco, F.; Bellan, M.F.; Aizpuru, M.; Gauquelin, T.; Denis, J. A remote sensing based methodology for mangrove studies in Madagascar. Int. J. Remote Sens. 1998, 19, 1873-1886.

60. Pasqualini, V.; Iltis, J.; Dessay, N.; Lointier, M.; Guelorget, O.; Polidori, L. Mangrove mapping in North-Western Madagascar using SPOT-XS and SIR-C radar data. Hydrobiologia 1999, 413, $127-133$.

61. Guillet, M.; Renou, E.; Robin, M.; Debaine, F.; Ratsivalaka, S. Suivi et analyze de l'evolution de la mangrove de Mahajamba (Nord-ouest de Madagascar). In Proceedings of the International Pluridisciplinary Conference, Lille, France, 16-18 January 2008.

62. Rasofolo, M.V. Use of mangroves by traditional fishermen in Madagascar. Mangroves Salt Marshes 1997, 1, 243-253.

63. Cornell University, 2001. The Commune Census by the ILO program of Cornell University in collaboration with FOFIFA and INSTAT. Available online: http://www.ilo.cornell.edu/ilo /data.html (accessed on 1 June 2012).

64. Mayaux, P.; Gond, V.; Bartholome, E. A near-real time forest-cover map of Madagascar derived from SPOT-4 VEGETATION data. Int. J. Remote Sens. 2000, 21, 3139-3144.

65. Critical Ecosystem Partnership Fund (CEPF). Madagascar Vegetation Mapping Project; CEPF: Arlington, VA, USA, 2007.

66. Harper, G.J.; Steininger, M.K.; Tucker, C.J.; Juhn, D.; Hawkins, F. Fifty years of deforestation and forest fragmentation in Madagascar. Environ. Conserv. 2007, 34, 325-333.

67. Richards, M.; Panfil, S.N. Social and Biodiversity Impact Assessment (SBIA) Manual for REDD+ Projects: Part 1-Core Guidance for Project Proponents; Climate, Community \& Biodiversity Alliance, Forest Trends, Fauna \& Flora International, and Rainforest Alliance: Washington, DC, USA, 2011.

68. Richards, M. Social and Biodiversity Impact Assessment (SBIA) Manual for REDD+ Projects: Part 2-Social Impact Assessment Toolbox; Climate, Community \& Biodiversity Alliance and Forest Trends with Rainforest Alliance and Fauna \& Flora International: Washington, DC, USA, 2011.

69. Chavez, P.S. Image-based atmospheric corrections: Revisited and improved. Photogramm. Eng. Remote Sens. 1996, 62, 1025-1036. 
70. Kirui, K.B.; Kairo, J.G.; Bosire, J.; Viergever, K.M.; Rudra, S.; Huxham, M.; Briers, R.A. Mapping of mangrove forest land cover change along the Kenya coastline using Landsat imagery. Ocean Coast. Manag. 2013, 83, 19-24.

71. Simard, M.; Zhang, K.Q.; Rivera-Monroy, V.H.; Ross, M.S.; Ruiz, P.L.; Castaneda-Moya, E.; Twilley, R.R.; Rodriguez, E. Mapping height and biomass of mangrove forests in Everglades National Park with SRTM elevation data. Photogramm. Eng. Remote Sens. 2006, 72, 299-311.

72. Fatoyinbo, T.E.; Simard, M.; Washington-Allen, R.A.; Shugart, H.H. Landscape-scale extent, height, biomass, and carbon estimation of Mozambique's mangrove forests with Landsat ETM+ and Shuttle Radar Topography Mission elevation data. J. Geophys. Res. Biogeosci. 2008, 113, doi:10.1029/2007JG000551.

73. Simard, M.; Rivera-Monroy, V.H.; Mancera-Pineda, J.E.; Castaneda-Moya, E.; Twilley, R.R. A systematic method for 3D mapping of mangrove forests based on Shuttle Radar Topography Mission elevation data, ICEsat/GLAS waveforms and field data: Application to Cienaga Grande de Santa Marta, Colombia. Remote Sens. Environ. 2008, 112, 2131-2144.

74. Fatoyinbo, T.E.; Simard, M. Height and biomass of mangroves in Africa from ICESat/GLAS and SRTM. Int. J. Remote Sens. 2013, 34, 668-681.

75. Aslan, A.; Rahman, A.F.; Warren, M.; Robeson, S.M.; Darusman, T. Combined Use of Active and Passive Remote Sensing for Mapping Distribution and Biomass of Coastal Mangroves. In Proceedings of the 2014 AGU fall meeting, San Francisco, CA, USA, 15-19 December 2014; p. 0093.

76. Bhattarai, B.; Giri, C. Assessment of mangrove forests in the Pacific region using Landsat imagery. J. Appl. Remote Sens. 2011, 5, 053509.

77. Long, J.B.; Giri, C. Mapping the Philippines' mangrove forests using Landsat imagery. Sensors 2011, 11, 2972-2981.

78. Tomlinson, P.B. The Botany of Mangroves; Cambridge University Press: Melbourne, Australia, 1986.

79. Aschbacher, J.; Ofren, R.; Delsol, J.P.; Suselo, T.B.; Vibulsresth, S.; Charrupat, T. An integrated comparative approach to mangrove vegetation mapping using advanced remote sensing and GIS technologies: Preliminary results. Hydrologica 1995, 295, 285-295.

80. Gao, J.A. Hybrid method toward accurate mapping of mangroves in a marginal habitat from SPOT Multispectral data. Int. J. Remote Sens. 1998, 19, 1887-1899.

81. Green, E.P.; Clark, C.D.; Mumby, P.J.; Edwards, A.J.; Ellis, A.C. Remote sensing techniques for mangrove mapping. Int. J. Remote Sens. 1998, 19, 935-956.

82. Gao, J.A. Comparative study on spatial and spectral resolutions of satellite data in mapping mangrove forests. Int. J. Remote Sens. 1999, 20, 2823-2833.

83. Saito, H.; Bellan, M.F.; Al-Habshi, A.; Aizpuru, M.; Blasco, F. Mangrove research and coastal ecosystem studies with SPOT-4 HRVIR and TERRA ASTER in Arabian Gulf. Int. J. Remote Sens. 2003, 24, 4073-4092.

84. Tong, P.H.; Auda, Y.; Populus, J.; Aizpura, M.; Habshi, A.A.; Blasco, F. Assessment from space of mangroves evolution in the Mekong Delta, in relation to extensive shrimp farming. Int. J. Remote Sens. 2004, 25, 4795-4812.

85. Jensen, L.S.; Mueller, T.; Tate, K.R.; Ross, D.J.; Magid, J.; Nielsen, N.E. Soil surface CO2 flux as an index of soil respiration in situ: A comparison of two chamber methods. Soil Biol. Biochem. 1996, 28, 1297-1306. 
86. Kauffman, J.B.; Donato, D.C. Protocols for the Measurement, Monitoring and Reporting of Structure, Biomass and Carbon Stocks in Mangrove Forests. Working Paper 86; CIFOR: Bogor, Indonesia, 2012.

87. Kauffman, J.B.; Heider, C.; Cole, T.G.; Dwire, K.A.; Donato, D.C. Ecosystem carbon stocks of Micronesian mangrove forests. Wetlands 2011, 31, 343-352.

88. Komiyama, A.; Poungparn, S.; Kato, S. Common allometric equations for estimate the tree weight of mangroves. J. Trop. Ecol. 2005, 21, 471-477.

89. Simpson, W.T. Method to Estimate Dry-Kiln Schedules and Species Groupings: Tropical and Temperate Hardwoods; US Department of Agriculture, Forest Service, Forest Products Laboratory: Washington, DC, USA, 1996.

90. Dharmawan, I.W.S.; Siregar, C.A. Soil carbon and carbon estimation of Avicennia marina (Forsk). Vierh. Stand at Ciasem, Purwakarta. J. Penelit. Hutan dan Konservasi Alam. 2008, 5, 317-328.

91. Clough, B.F.; Scott, K. Allometric relationships for estimating above-ground biomass in six mangrove species. For. Ecol. Manag. 1989, 27, 117-127.

92. Chave, J., Andalo, C., Brown, S., Cairns, M.A., Chambers, J.Q., Eamus, D., Fölster, H., Fromard, F., Higuchi, N., Kira, T. et al. Tree allometry and improved estimation of carbon stocks and balance in tropical forests. Oecologia 2005, 145, 87-99.

93. Cole, T.G., Ewel, K., Devoe, N.N. Structure of mangrove trees and forests in Micronesia. For. Ecol. Manag. 1999, 117, 95-109.

94. Comley, B.W.T.; McGuinness, K.A. Above- and below-ground biomass, and allometry, of four common northern Australian mangroves. Aust. J. Bot. 2005, 53, 431-436.

95. Sinclair, T.T.; Hoffer, R.M.; Schreiber, M.M. Reflectance and internal structure of leaves from several crops during a growing season. Agron. J. 1971, 63, 864-868.

96. Elvidge, C.D. Visible and near-infrared reflectance characteristics of dry plant materials. Int. J. Remote Sens. 1990, 11, 1775-1795.

97. Curran, P.J. Remote sensing of foliar chemistry. Remote Sens. Environ. 1989, 30, 271-278.

98. Tamura, M.; Kikushima, K. Extraction of mangrove forests using a satellite image and a digital elevation model. In Remote Sensing for Agriculture, Ecosystems, and Hydrology X; SPIE: Cardiff, UK, 2008; Volume 7104.

99. Plugge, D.; Baldauf, T.; Ratsimba, H.R.; Rajoelison, G.; Köhl, M. Combined biomass inventory in the scope of REDD (Reducing Emissions from Deforestation and Forest Degradation). Madag. Conserv. Dev. 2010, 5, 23-34.

100. Jones, T.G.; Ratsimba, H.R.; Carro, A.; Ravaoarinorotsihoarana, L.; Glass, L.; Teoh, M.; Benson, L., Cripps, G.; Giri, C.; Zafindrasilivonona, B.; et al. The mangroves of Ambanja and Ambaro Bays, northwest Madagascar: Historical dynamics, current status and deforestation mitigation strategy. In Estuaries: a Lifeline of Ecosystem Services in Western Indian Ocean; Diop, S., Scheren, P., Eds.; Springer: Berlin, Germany, 2015.

101. Stringer, C.E.; Trettin, C.C.; Zarnoch, S.J.; Tang, W. The Zambezi River Delta Mangrove Carbon Project: A Pilot Baseline Assessment for REDD+ Reporting and Monitoring; United States Forest Service: Washington, DC, USA, 2014. 
102. Adame, M.F.; Kauffman, J.B.; Medina, I.; Gamboa, J.N.; Torres, O.; Caamal, J.P.; Reza, M.; Herrera-Silveira, J.A. Carbon stocks of tropical coastal wetlands within the Karstic landscape of the Mexican Caribbean. PLoS ONE 2013, 8, e56569.

103. Kauffman, J.B.; Cole, T.G. Micronesian mangrove forest structure and tree responses to a severe typhoon. Wetlands 2010, 30, 1077-1084.

104. Twilley, R.R.; Chen, R.H.; Hargis, T. Carbon sinks in mangroves and their implications to carbon budget of tropical coastal ecosystems. Water Air Soil Pollut. 1992, 64, 265-288.

105. Komiyama, A.; Ong, J.E.; Poungparn, S. Allometry, biomass, and productivity of mangrove forests: A review. Aquat. Bot. 2008, 89, 128-137.

106. Alongi, D.M. The Energetics of Mangrove Forests; Springer Science and Business Media BV: New York, NY, USA, 2009.

107. Kairo, J.G.; Bosire, J.; Langat, J.; Kirui, B.; Koedam, N. Allometry and biomass distribution in replanted mangrove plantations at Gazi Bay, Kenya. Aquat. Conserv. 2009, 19, S63-S69.

108. Camacho, L.D.; Gevana, D.T.; Carandang, A.P.; Sofronio, C.C.; Combalicer, E.A.; Rebugio, L.L.; Youn, Y.-C. Tree biomass and carbon stock of a community-managed mangrove forest in Bohol, Phillipines. For. Sci. Technol. 2011, 7, 161-167.

109. Mitra, A.; Sengupta, K.; Banerjee, K. Standing biomass and carbon storage of above-ground structures in dominant mangrove trees in the Sundarbans. For. Ecol. Manag. 2011, 261, 1325-1335.

110. Abino, A.C.; Castillo, J.A.A.; Lee, Y.J. Assessment of species diversity, biomass and carbon sequestration potential of a natural mangrove stand in Samar, the Philippines. For. Sci. Technol. 2013, 10, 2-8.

111. Hutchison, J.; Manica, A.; Swetnam, R.; Balmford, A.; Spalding, M. Predicting global patterns in mangrove forest biomass. Conserv. Lett. 2013, 7, 233-240.

112. Cohen, R.; Kaino, J.; Okello, J.A.; Bosire, J.O.; Kairo, J.G.; Huxham, M.; Mencuccini, M. Propogating uncertainty to estimates of above-ground biomass for Kenyan mangroves: A scaling procedure from tree to landscape level. For. Ecol. Manag. 2013, 310, 968-982.

113. Ajonina, G.N.; Kairo, J.; Grimsditch, G.; Sembres, T.; Chuyong, G.; Diyouke, E. Assessment of mangrove carbon stocks in Cameroon, Gabon, the Republic of Congo (RoC) and the Democratic Republic of Congo (DRC) including their potential for reducing emissions from deforestation and forest degradation (REDD+). In The Land/Ocean Interactions in the Coastal Zone of West and Central Africa; Diop, S., Barusseau, J.-P., Descamps, C., Eds.; Springer International Publishing: Berlin, Germany, 2014; pp. 177-189.

114. Hamilton, S.E.; Lovette, J. Ecuador's Mangrove Forest Carbon Stocks: A Spatiotemporal Analysis of Living Carbon Holdings and Their Depletion since the Advent of Commercial Aquaculture. PLOS ONE 2015, 10, e0118880.

115. Golley, F.; Odum, H.T.; Wilson, R.F. The structure and metabolism of a Puerto Rican red mangrove forest in May. Ecology 1962, 43, 9-19.

116. Eong, O.J. Mangroves-A carbon source and sink. Chemosphere 1993, 27, 1097-1107.

117. Matsui, N. Estimated stocks of organic carbon in mangrove roots and sediments in Hinchinbrook Band, Australia. Mangroves Salt Marshes 1998, 2, 199-204.

118. Fujimoto, K.; Imaya, A.; Tabuchi, R.; Kuramoto, S.; Utsugi, H.; Murofushi, T. Belowground C storage of Micronesian mangrove forests. Ecol. Res. 1999, 14, 409-413. 
119. Ray, R.; Ganguly, D.; Chowdhury, C.; Dey, M.; Das, S.; Dutta, M.K.; Mandal, S.K.; Majumder, N.; De, T.K.; Mukhopadhyay, S.K.; et al. Carbon sequestration and annual increase of carbon stock in a mangrove forest. Atmos. Environ. 2011, 45, 5016-5024.

120. Chen, L.; Zeng, X.; Tam, N.F.Y.; Lu, W.; Luo, Z.; Du, X.; Wang, J. Comparing carbon sequestration and stand structure of monoculture and mixed mangrove plantations of Sonneratia caseolaris and S. apetala in Southern China. For. Ecol. Manag. 2012, 284, 222-229.

121. Wang, G.; Dongsheng, G.; Peart, M.R.; Chen, Y.; Peng, Y. Ecosystem carbon stocks of mangrove forest in Yingluo Bay, Guangdon Province of South China. For. Ecol. Manag. 2013, 310, 539-546.

122. Jardine, S.L.; Siikamäki, J.V. A global predictive model of carbon in mangrove soils. Environ. Res. Lett. 2014, 9, 104013.

123. Liu, H.; Ren, H.; Hui, D.; Wang, W.; Liao, B.; Cao, Q. Carbon stocks and potential carbon storage in the mangrove forests of China. J. Environ. Manag. 2014, 133, 86-93.

124. De la Cruz, A.A. Tropical wetlands as a carbon source. Aquat. Bot. 1986, 25, 109-115.

125. Hooijer, A.; Silvius, M.; Wösten, H.; Page, S. PEAT-CO2: Assessment of CO2 Emissions from Drained Peatlands in SE Asia, Delft Hydraulics, Report Q3943, 1st ed.; Wetlands International, Delft Hydraulics: Delft, The Netherlands, 2006.

126. Grimsditch, G.; Alder, J.; Nakamura, T.; Kenchington, R.; Tamelander, J. The blue carbon special edition-Introduction and overview. Ocean Coast. Manag. 2013, 83, 1-4.

127. Alongi, D.M. Carbon Cycling and Storage in Mangrove Forests. Annu. Review Mar. Science 2014, 6, 195-219.

128. Schumacher, B. Methods for the Determination of Total Organic Carbon (TOC) in Soils and Sediments; Ecological Risk Assessment Support Center, Office of Research and Development; US Environmental Protection Agency: Washington, DC, USA, 2002.

129. Mikhailova, E.A.; Noble, R.R.P.; Post, C.J. Comparison of soil organic carbon recovery by Walkley-Black and dry combustion methods in the Russian Chernozem. Commun. Soil Sci. Plant Anal. 2003, 34, 1853-1860.

130. De Vos, B.; Letterns, S.; Muys, B.; Deckers, J.A. Walkley-Black analysis of forest soil organic carbon: Recovery, limitations and uncertainty. Soil Use Manag. 2007, 23, 221-229.

131. Meersmans, J.; van Wesemael, B.; van Molle, M. Determining soil organic carbon for agricultural soils: A comparison between the Walkley \& Black and the dry combustion methods (north Belgium). Soil Use Manag. 2009, 25, 346-353.

(C) 2015 by the authors; licensee MDPI, Basel, Switzerland. This article is an open access article distributed under the terms and conditions of the Creative Commons Attribution license (http://creativecommons.org/licenses/by/4.0/). 